\title{
Summary of Results for PHA Glass Study: Composition and Property Measurements
}

by

T. B. Edwards

Westinghouse Savannah River Company

Savannah River Site

Aiken, South Carolina 29808

J. R. Harbour

R. J. Workman

This paper was prepared in connection with work done under the above contract number with the U.S.

Department of Energy. By acceptance of this paper, the publisher and/or recipient acknowledges the U. S. Government's right to retain a nonexclusive, royalty-free license in and to any copyright covering this paper, along with the right to reproduce and to authorize others to reproduce all or part of the copyrighted paper. 
WSRC-TR-99-00332

Revision 0

Keywords: Coupled Operation, DWPF, Liquidus Temperature, PCCS, PCT, Salt Disposition, Viscosity

Retention Time: Permanent

\section{SUMMARY OF RESULTS FOR PHA GLASS STUDY: COMPOSITION AND PROPERTY MEASUREMENTS (U)}

T. B. Edwards

J. R. Harbour

R. J. Workman

Westinghouse Savannah River Company

Savannah River Technology Center Aiken, SC 29808

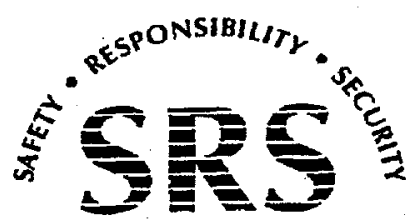

SAVANNAH RIVER SITE

PREPARED FOR THE U.S. DEPARTMENT OF ENERGY UNDER CONTRACT NO. DE-AC09-96SR18500 
WSRC-TR-99-00332

Revision 0

\section{DISCLAIMER}

This report was prepared as an account of work sponsored by an agency of the United States Government. Neither the United States Government nor any agency thereof, nor any of their employees, makes any warranty, express or implied, or assumes any legal liability or responsibility for the accuracy, completeness, or usefulness of any information, apparatus, product, or process disclosed, or represents that its use would not infringe privately owned rights. Reference herein to any specific commercial product, process, or service by trade name, trademark, manufacturer, or otherwise does not necessarily constitute or imply its endorsement, recommendation, or favoring by the United States Government or any agency thereof. The views and opinions of authors expressed herein do not necessarily state or reflect those of the United States Government or any agency thereof.

This report has been reproduced directly from the best available copy.

Available to DOE and DOE contractors from the Office of Scientific and Technical Information, P.O. Box 62, Oak Ridge, TN 37831; prices available from (615) 576-8401.

Available to the public from the National Technical Information Service, U.S. Department of Commerce; 5285 Port Royal Road, Springfield, VA 22161. 


\section{DISCLAIMER}

\section{Portions of this document may be illegible in electronic image products. Images are produced from the best available original document.}




\section{Summary of Results for PHA Glass Study: Composition and Property Measurements (U)}

September 9, 1999

Document Approvals

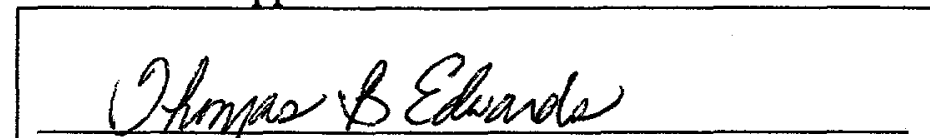

T. B. Edwards, Author

Statistical Consulting Section

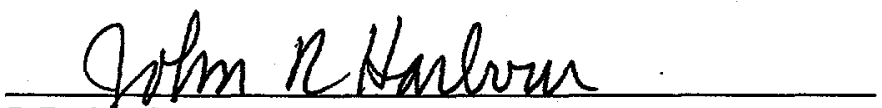

J. R. Harbour, Author

Immoblization Technology Section

Phondag. Hortua

R. J. Workman, Author

Immobilization Technology Section

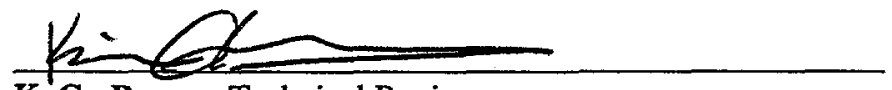

K. G. Brown, Technical Review

Immobilization Technology Section

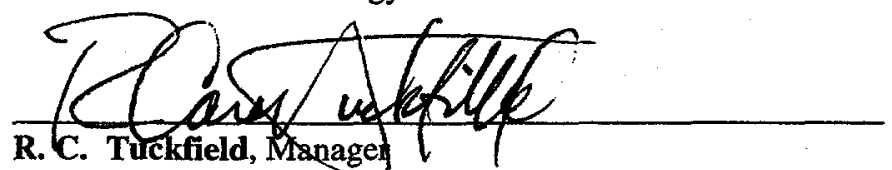

Statistical Consulting Section

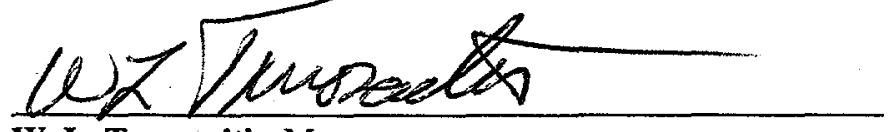

W. L. Tamosaitis, Manager

Waste Processing Technology Section

\section{Ev dretzented}

E. W. Holtzscheitel, Manager

Immobilization Technology Section

Authorized Derivative Classifier

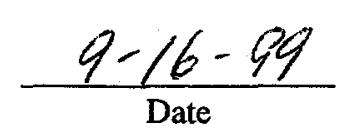

$\frac{9-16-99}{\text { Date }}$

$\frac{9-16-99}{\text { Date }}$
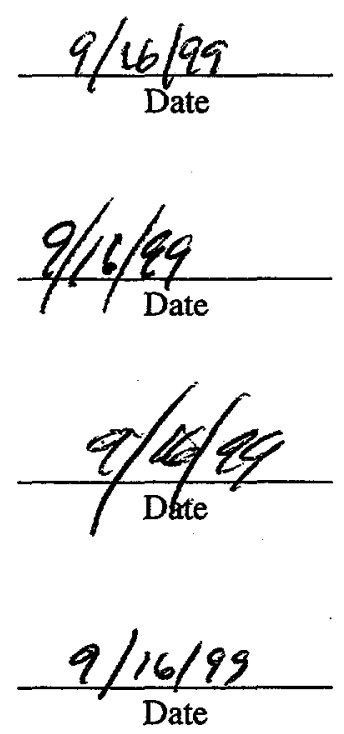

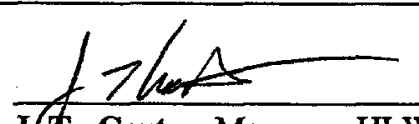

J.T. Carter, Manager, HLW Process Engineering

Signature Signifies Satisfactory Completion of PHA Glass Study

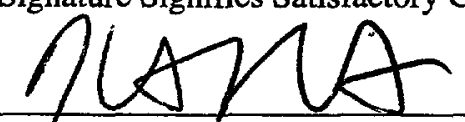

K. J. Rueter, Director, Salt Disposition Engineering

Signature Signifies Satisfactory Completion of PHA Glass Study
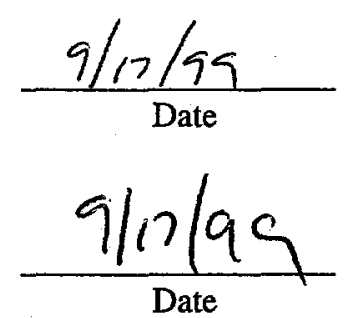
This page intentionally left blank. 


\section{TABLE OF CONTENTS}

Summary and Conclusions ......................................... 1

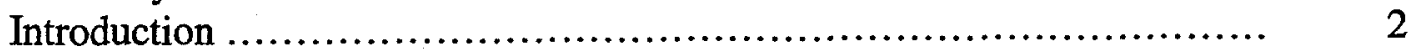

Results and Discussion ............................................... 4

Target and Measured Chemical Compositions ..................... 4

PCT Results .................................................... 5

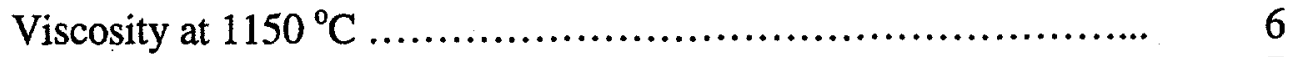

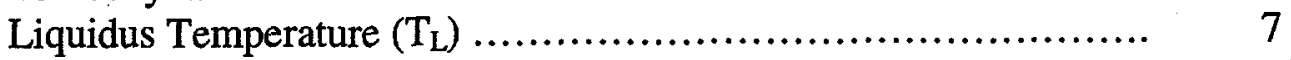

Surface Crystallization ......................................... 10

Phase Separation ............................................... 11

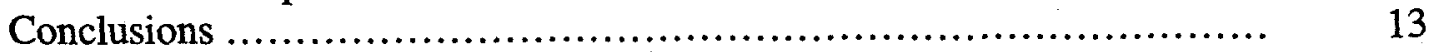

References ........................................................... 15

Appendix: Supplemental Tables and Exhibits .......................... 17 
WSRC-TR-99-00332

Revision 0

This page intentionally left blank. 


\section{SUMMARY AND CONCLUSIONS}

This report provides a summary of the results obtained for a limited variability study for glasses containing Precipitate Hydrolysis Aqueous (PHA), Monosodiumtitanate (MST), and either simulated Purex or HM sludge. Twenty glasses containing Purex sludge and three glasses containing HM sludge were fabricated and tested. The fabricated glasses were tested for durability using the Product Consistency Test (PCT) and characterized by measuring the melt viscosity and an approximate, bounding liquidus temperature. The current models used by Defense Waste Processing Facility (DWPF) for predicting durability, viscosity, and liquidus temperature were applied to all 23 glasses. The goal of this work was to identify any major problems from a glass perspective that could potentially preclude the use of higher levels of PHA and MST at DWPF.

The selection of Purex sludge for the majority of the glasses fabricated in this study was based on the knowledge that this sludge type has historically been the most difficult sludge to incorporate into glass. Depleted uranium was introduced into the simulated Purex sludge to better represent the uranium content ( 9 wt\% oxide) of actual sludge.

One of the major concerns for this study was the effect of higher levels of PHA in the glass. The plan for this work was to vary the PHA level from 7 to $13 \mathrm{wt} \%$ oxide, which can be compared to the expected/design basis of 6 to $8 \mathrm{wt} \%$ oxide. Another concern was the potential for higher levels of titanium (from MST) into the glass. The current limit for $\mathrm{TiO}_{2}$ in the DWPF glass is 1 wt\% whereas the scope of this work varied the $\mathrm{TiO}_{2}$ level from 1 to $2 \mathrm{wt} \%$.

Frit 202 was used in this study and was the frit originally designed for coupled operations at DWPF.

As part of this study, the model predictions were made using targeted, measured, and bias-corrected measured compositions of the glasses. For glasses where there were no batching difficulties, it was demonstrated that the results were essentially insensitive to the type of composition used in these models. This provides evidence that the glasses produced were close to the targeted compositions, and that the analytical measurements were of high quality.

Glass Durability. All 23 glasses were very durable as measured by the PCT. The values ranged from 0.90 to $1.76 \mathrm{~g} / \mathrm{L}$ for boron release for the Purex glasses and from 0.45 to $0.50 \mathrm{~g} / \mathrm{L}$ for boron release for the HM glasses. For comparison, the reference Environmental Assessment (EA) glass has a boron rate of $16.7 \mathrm{~g} / \mathrm{L}$.

Model Prediction of Durability. The PCCS durability model predicted values for boron release that were all within the $95 \%$ prediction limits of the model.

Homogeneity. The durability model was developed for glasses that are not phase separated (amorphous) and this is controlled through application of a homogeneity discriminator. The majority of the glasses ( 17 of the 23 glasses) failed this discrimination model. The PCT results for the glasses of this study (all of which were rapidly quenched) revealed that measured durability is not a function of predicted phase separation based upon the current homogeneity model. Further work (including kinetic studies) is required to resolve this apparent inconsistency.

Liquidus. For this study, the liquidus temperature was bounded by performing 24-hour isothermal holds (as required) for the glass melts at $900^{\circ} \mathrm{C}, 950^{\circ} \mathrm{C}, 1000^{\circ} \mathrm{C}$, and $1050^{\circ} \mathrm{C}$. X-ray diffraction was used to detect crystallization, in this case Trevorite. For the $22 \mathrm{wt} \%$ and $26 \mathrm{wt} \%$ Purex glasses, no crystals were detected in the bulk at $900^{\circ} \mathrm{C}$ or at the top surface of the glasses. For the $30 \mathrm{wt} \%$ Purex glasses, crystals were evident at temperatures higher than $900^{\circ} \mathrm{C}$, but at $1000^{\circ} \mathrm{C}$ they were below the XRD detection limit. Given the fact that liquidus temperatures were only approximated, the $30 \mathrm{wt} \%$ loading of Purex may be near or at the edge of acceptability for liquidus. A small amount of surface crystallization (after the isothermal hold at $900^{\circ} \mathrm{C}$ ) was evident on the glass surface near the center of 
the crucible for four of the $30 \mathrm{wt} \%$ Purex glasses. The crystals detected were Trevorite. For HM glasses, no crystals were detected in the bulk or on the surface after 24 hours at $900^{\circ} \mathrm{C}$.

Viscosity. The melt viscosities for 11 of these 23 glasses were measured and predictions reported at $1150^{\circ} \mathrm{C}$ (nominal temperature of the glass within the DWPF melter). For the Purex containing glasses, the measured viscosities were within the DWPF range of 20 to 100 poise for the $22 \mathrm{wt} \%$ and $26 \mathrm{wt} \%$ Purex glasses. However, the $30 \mathrm{wt} \%$ Purex glasses had viscosities that were very near the lower limit of 20 poise, and consequently, may not be acceptable from an operations perspective. Although the HM sludge glass measured (10wt\% PHA) had a viscosity of $\sim 90$ poise, the HM glasses at $7 \mathrm{wt} \%$ PHA are predicted to be higher than the 100 poise limit for DWPF.

Limitations. All of the conclusions are provided based on the scope of the current work. One limitation of this scope, based upon schedule and budget, was the absence of any investigation of kinetic effects. Thus, one can not rule out that amorphous phase separation occurs with centerline cooling, for example. A second limitation was the restriction on independent variation of chemical constituents. In a major variability study, ranges are established for each element, and a statistically designed set of glasses identified which not only covers a larger region of compositional space, but also provides the potential for revealing trends in the properties over linear variations of elemental concentrations. A third limitation was that only approximate measurements of the liquidus temperatures were made. A fourth limitation was that a thorough search (beyond scanning electron microscopy) for phase separation was not conducted. This type of investigation requires considerable efforts using transmission electron microscopy (TEM) and other high resolution techniques. Finally, although the strategy was that HM and Purex containing glasses would cover the extremes, no Blend sludge glasses were fabricated to verify this.

\section{INTRODUCTION}

One of the Alternative Salt Disposition Flowsheets being considered would require that the Defense Waste Processing Facility (DWPF) vitrify a coupled feed containing High Level Waste (HLW) and Precipitate Hydrolysis Aqueous (PHA). A Technical Task Request (TTR) [1] was received by the Savannah River Technology Center (SRTC) requesting that a glass variability study be conducted to explore the processability and product quality of the glass composition region for this alternative (Small Tank TPB Precipitation) to the In-Tank Precipitation (ITP) Process. A Task Technical and Quality Assurance (TT\&QA) plan [2] was issued by SRTC in response to the TTR. The objective of this task was to obtain information on the feasibility of incorporating anticipated levels of PHA into DWPF glass with and without doubling the nominal levels of monosodium titanate (MST). The study progressed through four phases of investigation, the detailed results of which have each been issued in technical reports (see references [3] through [6]). The purpose of this final report is to consolidate the results of these four phases and provide overall conclusions.

Table 1 provides a general overview of the glass compositions that were batched, fabricated, and tested as part of this study. The glasses were selected from a set of candidate glasses that involved three sludge types: Purex, HM, and Blend; covered sludge loadings (in the glass) of 22, 26, and 30 oxide weight percent (wt\%); utilized PHA loadings (in the glass) of 7, 10, and 13 oxide wt\%; and included MST concentrations (in the glass) at 1.25 and $2.5 \mathrm{wt} \%$. For each composition, the remainder of the glass consisted of Frit 202. The goal of using Purex sludge as the major sludge type with only a few glasses containing HM was realized. However, no glasses were fabricated using the Blend sludge (a sludge representing the combination of HM and Purex). In all likelihood, DWPF macrobatches will be blends of tanks containing various waste/sludge types. 
Table 1: General Compositions of the PHA Glasses

\begin{tabular}{|c|c|c|c|c|c|c|}
\hline Phase & $\begin{array}{c}\text { Glass } \\
\text { ID }\end{array}$ & $\begin{array}{c}\text { Sludge } \\
\text { Type }\end{array}$ & $\begin{array}{l}\text { Sludge } \\
\text { Loading }\end{array}$ & PHA & MST & $\begin{array}{l}\text { Frit } \\
202\end{array}$ \\
\hline 1 & pha07 & Purex & $26 \%$ & $7 \%$ & $1.25 \%$ & $65.75 \%$ \\
\hline 1 & pha08 & Purex & $26 \%$ & $10 \%$ & $1.25 \%$ & $62.75 \%$ \\
\hline 1 & pha09 & Purex & $26 \%$ & $13 \%$ & $1.25 \%$ & $59.75 \%$ \\
\hline 1 & pha10 & Purex & $26 \%$ & $7 \%$ & $2.50 \%$ & $64.50 \%$ \\
\hline 1 & pha11 & Purex & $26 \%$ & $10 \%$ & $2.50 \%$ & $61.50 \%$ \\
\hline 1 & pha12 & Purex & $26 \%$ & $13 \%$ & $2.50 \%$ & $58.50 \%$ \\
\hline 2 & pha13 & Purex & $30 \%$ & $7 \%$ & $1.25 \%$ & $61.75 \%$ \\
\hline 2 & pha14 & Purex & $30 \%$ & $10 \%$ & $1.25 \%$ & $58.75 \%$ \\
\hline 2 & pha15 & Purex & $30 \%$ & $13 \%$ & $1.25 \%$ & $55.75 \%$ \\
\hline 2 & pha16 & Purex & $30 \%$ & $7 \%$ & $2.50 \%$ & $60.50 \%$ \\
\hline 2 & pha17 & Purex & $30 \%$ & $10 \%$ & $2.50 \%$ & $57.50 \%$ \\
\hline 2 & pha18 & Purex & $30 \%$ & $13 \%$ & $2.50 \%$ & $54.50 \%$ \\
\hline 3 & pha01 & Purex & $22 \%$ & $7 \%$ & $1.25 \%$ & $69.75 \%$ \\
\hline 3 & phaO2 & Purex & $22 \%$ & $10 \%$ & $1.25 \%$ & $66.75 \%$ \\
\hline 3 & pha03 & Purex & $22 \%$ & $13 \%$ & $1.25 \%$ & $63.75 \%$ \\
\hline 3 & pha04 & Purex & $22 \%$ & $7 \%$ & $2.50 \%$ & $68.50 \%$ \\
\hline 3 & pha05 & Purex & $22 \%$ & $10 \%$ & $2.50 \%$ & $65.50 \%$ \\
\hline 3 & pha06 & Purex & $22 \%$ & $13 \%$ & $2.50 \%$ & $62.50 \%$ \\
\hline 4 & pha11c & Purex & $26 \%$ & $10 \%$ & $2.50 \%$ & $61.50 \%$ \\
\hline 4 & pha12c & Purex & $26 \%$ & $13 \%$ & $2.50 \%$ & $58.50 \%$ \\
\hline 4 & phal7c & Purex & $30 \%$ & $10 \%$ & $2.50 \%$ & $57.50 \%$ \\
\hline 4 & pha18c & Purex & $30 \%$ & $13 \%$ & $2.50 \%$ & $54.50 \%$ \\
\hline 4 & pha20 & HM & $22 \%$ & $10 \%$ & $1.25 \%$ & $66.75 \%$ \\
\hline 4 & pha26 & HM & $26 \%$ & $10 \%$ & $1.25 \%$ & $62.75 \%$ \\
\hline 4 & pha32 & $\mathbf{H M}$ & $30 \%$ & $10 \%$ & $1.25 \%$ & $58.75 \%$ \\
\hline
\end{tabular}

The primary property of interest in this study was the durability (as measured by the 7-day Product Consistency Test, PCT [7]) of the test glasses. The PCT is the recognized standard for determining the durability of vitrified HLW, and the Environmental Assessment (EA) glass is the reference standard for assessing acceptable durability determined using the PCT. ${ }^{1}$ The measurement of durability was conducted to the specifications of the PCT Method A of ASTM C1285 for each and every glass of this study. (See the analytical plan [8] and the individual phase reports, [3] through [6], for details.)

Processing properties of interest for these glasses included viscosity at $1150^{\circ} \mathrm{C}$ and liquidus temperature. Methods used to complete these two types of measurements did not follow standard ASTM procedures. However, viscosity was measured at SRTC using a Harrop viscometer [9] that has yielded good results [10]. The standard ASTM procedure for measuring liquidus temperature, $T_{L}$, uses a gradient furnace. Since no such capability exists at SRTC, it was beyond the scope of this study to pursue this process for obtaining $T_{L}$ measurements. To gain insight into this important processablility property for the PHA glasses, an attempt was made to obtain an upper bound on the $\mathrm{T}_{\mathrm{L}}$ 's using isothermal holds at $900,950,1000$, and $1050^{\circ} \mathrm{C}$ and (non-quantitative) XRD evaluations (with a sensitivity of $\sim 0.7$ to $1 \mathrm{wt} \%$ for crystalline Trevorite in the glass). The results from these measurements are presented in this final report (the reports for the individual phases ([3], [4], [5], and [6]) provide greater detail).

In the report for each phase of this study, comparisons were provided between

- the measured and target compositions of the test glasses and

- the property measurements and their predictions derived from models that are used by the Defense Waste Processing Facility (DWPF) as part of its Product Composition Control System (PCCS). These models relate processability and product quality (e.g., viscosity, $T_{L}$, and durability) to glass composition.

These comparisons have been consolidated and provided in the sections that follow.

1 For a glass to demonstrate acceptable durability its PCT leach rate must be 2-sigma better than the PCT leach rate of the EA glass. 


\section{RESULTS AND DISCUSSION}

The composition and property measurements of the glasses comprising the four phases of the PHA study were conducted in parallel with glasses from the corresponding phases of the other ITP replacement alternative, Crystalline Silicotitanate. This second study was designated as the CST study (references [11], [12], [13], and [14] provide the reports for the four phases of this study). Conducting the two studies in parallel helped to ensure that the CST and PHA glasses were fabricated, characterized, and analyzed under very similar conditions. For a full description of the analytical plans or of the review of the measurement data, see the individual reports for the phases of the PHA study [3]-[6].

\section{Target and Measured Chemical Compositions}

Table A.1 in the Appendix provides the target oxide compositions for each of the PHA glasses prepared using Purex sludge. Table A.2 in the Appendix provides the target oxide compositions for the three PHA glasses prepared using HM sludge.

Measurements of the compositions of the test glasses were conducted by the SRTC-Mobile Laboratory (SRTC-ML) or by the Analytical Development Section (ADS) of SRTC. Standards were included with the test glasses and bias-corrections were conducted for many of these measurements. Details are provided in the individual phase reports. The target, measured, and bias-corrected compositions of the glasses tested as part of this study are provided in Table A.3 of the Appendix. In most instances, the property predictions were essentially insensitive to the way the compositions of these glasses were represented (i.e., whether by the targeted, measured, or bias-corrected measurements). In certain instances discrepancies between target and measured compositions were investigated to gain insight into the batching and/or targeting processes.

One such discrepancy found during Phase 2 (glasses pha13-pha18) involving the components of PHA suggested a batching error centered on the use of anhydrous sodium borate versus hydrated sodium borate. Although the problem existed in all six Phase 2 glasses, those at the lowest levels of PHA (i.e., pha13 and pha16) were least affected. The other four glasses were re-batched as part of Phase 4 (i.e., glasses pha14c, pha15c, pha17c, and pha18c) of this study. Table A.3 contains the results for all of the PHA glasses, but the original glasses: pha14, pha15, pha17, and pha18 are excluded from the other analyses presented in this summary report. For full discussion of this discrepancy see reference [4], and for a discussion of the re-batched results see reference [6]. Exhibit A.1 in the Appendix provides plots of the compositions (target, measured, and bias corrected) of these glasses by oxide.

Another discrepancy, discovered during Phases 1 and 2, was the factor used to account for the MST components in the final glass product. This problem revealed itself in compositions that failed to meet the desired $\mathrm{TiO}_{2}$ targets and led to a re-evaluation of MST, a source of $\mathrm{TiO}_{2}$ in the glass. A subsequent analysis of MST revealed a larger than expected moisture content. The problem was corrected for Phase 3, and additional glasses (pha11c, pha12c, pha17c, and pha18c designated in Phase 4 with a "c" suffix, see Table 1) from the first two phases were introduced into Phase 4 . The $\mathrm{TiO}_{2}$ levels were met for Phases 3 and 4.

An additional comment about this exhibit and table is worth mentioning. The sum of oxides for all of these glasses fell within the interval of 95 to $105 \mathrm{wt} \%$, a measure of the quality of the analytical results. 


\section{PCT Results}

All of the PHA glasses, after being batched and fabricated, were subjected to the 7-day Product Consistency Test (PCT) as an assessment of their durabilities [7]. More specifically, Method A of PCT (ASTM C1285) was used for these measurements. Durability is the critical product quality metric for vitrified nuclear waste. The PCT responses (for four elements: boron, silicon, sodium, and lithium) were normalized to the units of grams-per-liter $(\mathrm{g} / \mathrm{L})$ using the measured, measured biascorrected, and target compositions. In addition to the PHA test glasses, the Environmental Assessment (EA) glass and the ARM glass were subjected to the PCT. The individual phase reports provide the details of the analytical plan and resulting data supporting these tests. The results from these tests are summarized in Table A. 4 of the Appendix.

As seen in Table A.4, the durabilities for the PHA glasses are much better than those of EA samples. Figure 1 provides an opportunity for a closer look at these results using measured and bias-corrected compositions. Figure 1 is a plot of the DWPF model that relates the common logarithm of the normalized PCT (in this case for B) to a linear function of a free energy of hydration term $\left(\Delta G_{p}\right.$, $\mathrm{kcal} / 100 \mathrm{~g}$ glass) derived from the glass (measured and bias-corrected) compositions [15]. Prediction limits (at 95\% confidence) for an individual (new) PCT result are also plotted around this linear fit. The PCT results for EA (shown as a diamond), ARM (shown as a " $z$ "), and the PHA glasses (each shown as an " $x$ ") are presented on this plot. Note that the PHA results reveal acceptable and predictable PCTs. Figure 2 provides a plot of the boron results based upon target compositions, which shows a similar pattern of behavior. Exhibit A2 in the Appendix provides similar plots of the PHA durability measurements versus the DWPF durability models for $\mathrm{B}, \mathrm{Si}, \mathrm{Na}$, and $\mathrm{Li}$. The behaviors seen in the plots for $\mathrm{Si}, \mathrm{Na}$, and $\mathrm{Li}$ are similar to that demonstrated by the $\mathrm{B}$ results: acceptable and predictable durabilities.

Figure 1.

$\log \mathbf{N L}(B)(g / L)$ By del Gp

(Using PHA Measured \& Bias-corrected \& EA and ARM reference compositions)
Figure 2.

$\log \mathrm{NL}(\mathrm{B})(\mathrm{g} / \mathrm{L})$ By del Gp

(Using target compositions for the PHA glasses \& EA and ARM reference compositions)
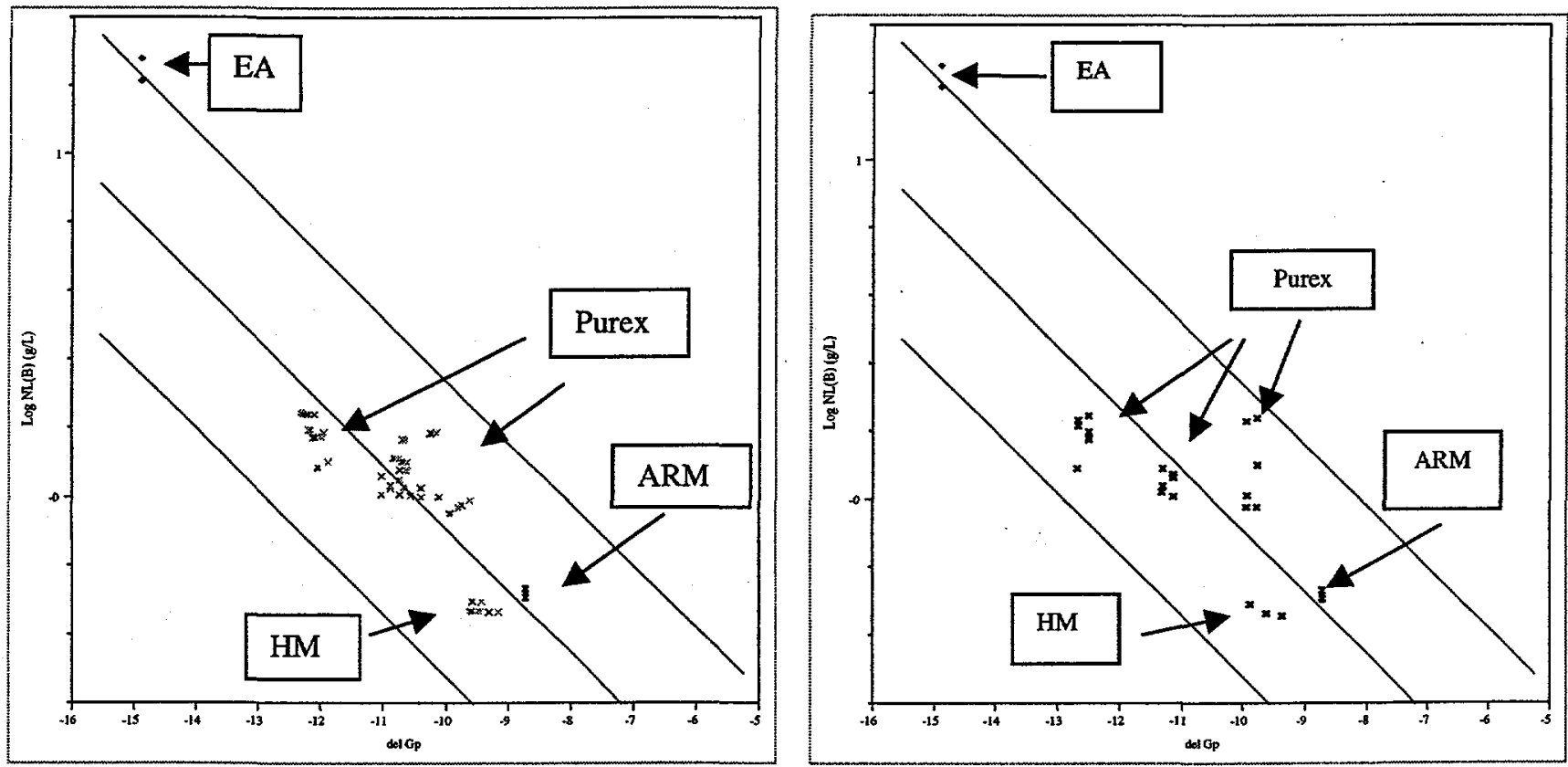


\section{Viscosity at $1150^{\circ} \mathrm{C}$}

Viscosity measurements were made on several of these PHA glasses at SRTC using a Harrop, hightemperature viscometer [9]. The viscosity (in Poise) of each of these glasses at $1150^{\circ} \mathrm{C}$ was estimated from a Fulcher equation fitted to a set of viscosity measurements taken over an appropriate range of temperatures. The functional form of the (three-parameter) Fulcher equation (expressed in Poise) used to fit these data is given by equation (1):

$$
\ln \hat{\eta}=A+\frac{B}{(T-C)}
$$

where $\mathrm{A}, \mathrm{B}$, and $\mathrm{C}$ represent the parameters of the model that were determined from the available measurements (represented by $\eta$, expressed in Poise) at various temperatures (represented by $T$ ). The fitted model was then used to predict the viscosity of the given glass at $1150^{\circ} \mathrm{C}$.

Although no definitive error analysis has been completed on the use of the Harrop viscometer, SRTC has conducted several sets of viscosity measurements using this viscometer with good results [10]. Viscosity measurements were not conducted for all of these PHA glasses. Table 2 provides the results that were obtained as part of this study.

Table 2: Viscosity Results (in Poise) By Glass ID for the PHA Glasses

\begin{tabular}{|ccccc|}
\hline Glass ID & $\begin{array}{c}\text { Viscosity } \\
\text { (Poise) }\end{array}$ & $\begin{array}{c}\text { Predicted } \\
\text { (measured } \\
\text { composition) }\end{array}$ & $\begin{array}{c}\text { Predicted } \\
\text { (bias-corrected } \\
\text { composition) }\end{array}$ & $\begin{array}{c}\text { Predicted } \\
\text { (target } \\
\text { composition) }\end{array}$ \\
pha01 & 43.9 & 57.7 & 57.7 & 70.2 \\
pha02 & Not measured & 56.0 & 60.8 & 53.1 \\
pha03 & 33.1 & 39.4 & 42.6 & 39.1 \\
pha04 & Not measured & 71.8 & 77.3 & 67.4 \\
pha05 & Not measured & 45.8 & 50.1 & 50.6 \\
pha06 & Not measured & 39.0 & 42.1 & 36.9 \\
pha07 & 52.6 & 65.7 & 66.1 & 58.0 \\
pha08 & 39.5 & 53.3 & 54.1 & 42.7 \\
pha09 & 31.8 & 42.7 & 44.0 & 30.5 \\
pha10 & 50.9 & 67.5 & 68.2 & 55.3 \\
pha11 & 37.7 & 59.4 & 60.7 & 40.4 \\
pha11c & Not Measured & 45.6 & 51.2 & 40.4 \\
pha12 & 29.2 & 42.1 & 43.4 & 28.5 \\
pha12c & 27.6 & 32.7 & 36.7 & 28.5 \\
pha13 & Not Measured & 42.4 & 45.4 & 46.7 \\
pha14c & Not Measured & 31.4 & N/A & 33.3 \\
pha15c & 22.8 & 22.0 & N/A & 23.0 \\
pha16 & Not Measured & 39.4 & 42.1 & 44.2 \\
pha17c & Not Measured & 32.7 & 37.1 & 31.3 \\
pha18c & Not Measured & 21.7 & 24.8 & 21.3 \\
pha20 & Not Measured & 96.7 & 105.8 & 102.0 \\
pha26 & Not Measured & 98.4 & 106.3 & 97.0 \\
pha32 & 89.7 & 90.4 & 99.5 & 91.9 \\
\hline
\end{tabular}

Figure 3 provides a plot of the measured viscosities versus the viscosities predicted from the DWPF model using target, measured, and bias-corrected compositions. A 45-degree (diagonal) line is also shown to provide a point of reference. 
Figure 3: Viscosity Measurements versus Property Predictions

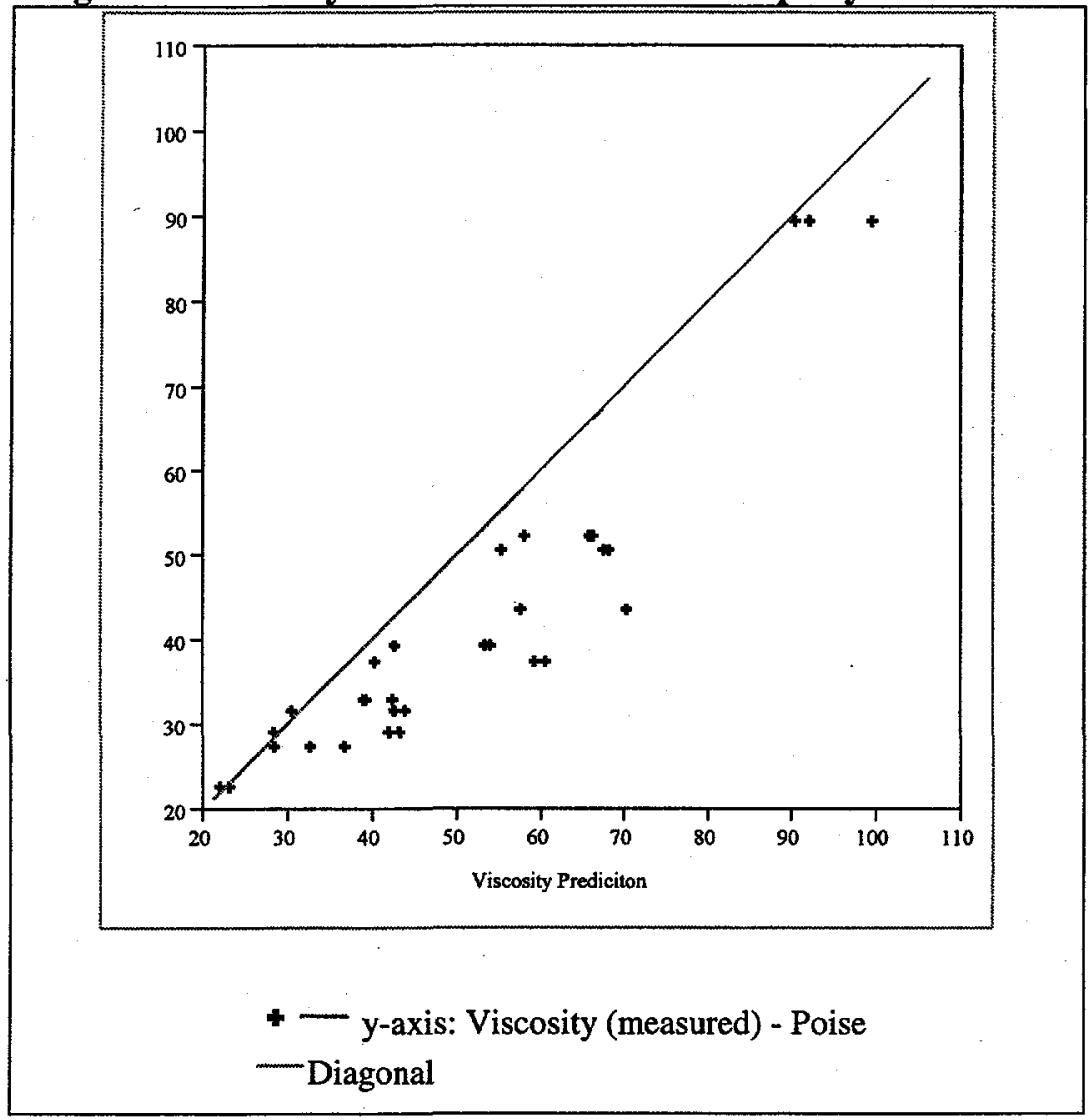

For the Purex glasses, the measured viscosities were within the DWPF range of 20 to 100 poise for the $22 \mathrm{wt} \%$ and $26 \mathrm{wt} \%$ Purex loadings. For these glasses, the measured viscosities ranged from 28 to 53 poise, values that are much lower than current operations. The measured viscosity of glass pha $12 \mathrm{c}$ is only 28 poise and is approaching the lower limit for viscosity. The results show, as expected, that the viscosity values decrease as the PHA concentration in the glass is increased.

For the $30 \mathrm{wt} \%$ Purex glasses at high PHA loadings, the measured viscosities were very near the lower limit of 20 poise and, consequently, may not be acceptable from an operations perspective. Although the HM sludge glass (pha32) had a measured viscosity of $~ 90$ poise at $10 \mathrm{wt} \%$ PHA, the HM glasses at 7 wt $\%$ PHA are predicted to be $\sim 120$ poise, a value that is significantly higher than the 100 poise upper limit for DWPF.

There are several interesting trends observed in these data. Whether one uses the target, measured, or bias-corrected measured compositions to predict viscosities using the current model, the predicted viscosities are almost always higher than the viscosities determined from measurements for the glasses batched using Purex sludge. This possible overprediction also occurs for the glasses made using HM sludge.

\section{Liquidus Temperature $\left(T_{L}\right)$}

The standard ASTM procedure for measuring liquidus temperature uses a gradient furnace. The equipment for determining liquidus temperature by this method is being installed and tested within SRTC in a clean laboratory. Due to the presence of depleted uranium in the glass samples (as well as the early stage of equipment setup), this method for liquidus determination was not available at SRTC for these analyses. A decision was therefore made to perform isothermal holds using reasonable quantities of the glass to bound the liquidus temperature. 
XRD was selected as the method of detection for crystal formation in the glasses after an isothermal hold. It is estimated that the sensitivity of XRD (non-quantitative) is $\sim 0.7$ to $1 \mathrm{wt} \%$ for a crystalline phase (in this case, Trevorite [16]). Therefore, for this type of measurement, absence of detection of a crystalline phase was evidence that the liquidus temperature is less than the temperature of that isothermal hold. On the other hand, detection of Trevorite (or any other primary crystalline phase) indicates that the liquidus temperature is higher than the temperature of the isothermal hold. The bounds on the liquidus temperatures for these PHA glasses, estimated to the detection capabilities of $\mathrm{XRD}$, are given in Table 3. The model predictions for $T_{L}$ based upon target, measured, and biascorrected compositions are also provided in this table.

\section{Table 3: Liquidus Temperature $\left({ }^{\circ} \mathrm{C}\right)$ By Glass ID for the CST Glasses}

\begin{tabular}{|ccccc|}
\hline Glass ID & $\begin{array}{c}\text { Estimated T } \\
\text { By Bounding } \\
\text { Procedure }\end{array}$ & $\begin{array}{c}\text { Predicted } \\
\text { (measured } \\
\text { composition) }\end{array}$ & $\begin{array}{c}\text { Predicted } \\
\text { (bias-corrected } \\
\text { composition) }\end{array}$ & $\begin{array}{c}\text { Predicted } \\
\text { (target } \\
\text { composition) }\end{array}$ \\
pha01 & $<900^{\circ} \mathrm{C}$ & 954.6 & 950.8 & 949.3 \\
pha02 & $<900^{\circ} \mathrm{C}$ & 957.1 & 949.4 & 956.1 \\
pha03 & $<900^{\circ} \mathrm{C}$ & 966.5 & 958.4 & 963.6 \\
pha04 & $<900^{\circ} \mathrm{C}$ & 923.1 & 917.3 & 952.0 \\
pha05 & $<900^{\circ} \mathrm{C}$ & 967.5 & 959.0 & 959.1 \\
pha06 & $<900^{\circ} \mathrm{C}$ & 968.5 & 960.3 & 966.9 \\
pha07 & $<900^{\circ} \mathrm{C}$ & 966.8 & 973.2 & 949.3 \\
pha08 & $<900^{\circ} \mathrm{C}$ & 973.2 & 980.0 & 956.1 \\
pha09 & $<900^{\circ} \mathrm{C}$ & 969.2 & 975.2 & 963.6 \\
pha10 & $<900^{\circ} \mathrm{C}$ & 953.7 & 959.3 & 952.0 \\
pha11 & $<900^{\circ} \mathrm{C}$ & 957.0 & 962.7 & 959.1 \\
pha11c & $<900^{\circ} \mathrm{C}$ & 987.3 & 977.5 & 1001.5 \\
pha12 & $<900^{\circ} \mathrm{C}$ & 973.1 & 979.2 & 966.9 \\
pha12c & $<900^{\circ} \mathrm{C}$ & 997.5 & 987.1 & 1012.2 \\
pha13 & $<900^{\circ} \mathrm{C}$ & 1040.7 & 1033.4 & 1032.9 \\
pha14c & $<1000^{\circ} \mathrm{C}$ & 1059.8 & $\mathrm{~N} / \mathrm{A}$ & 1045.4 \\
pha15c & $<1000^{\circ} \mathrm{C}$ & 1073.9 & $\mathrm{~N} / \mathrm{A}$ & 1059.3 \\
pha16 & $<900^{\circ} \mathrm{C}$ & 1039.7 & 1032.7 & 1037.9 \\
pha17c & $<1000^{\circ} \mathrm{C}$ & 1050.9 & 1037.6 & 1051.0 \\
pha18c & $<950^{\circ} \mathrm{C}$ & 1073.8 & 1059.2 & 1065.7 \\
pha20 & $<900^{\circ} \mathrm{C}$ & 916.2 & 910.2 & 906.3 \\
pha26 & $<900^{\circ} \mathrm{C}$ & 928.3 & 922.3 & 935.6 \\
pha32 & $<900^{\circ} \mathrm{C}$ & 959.2 & 950.8 & 970.7 \\
\hline
\end{tabular}

Figure 4 provides a comparison between the $T_{L}$ predictions of Table 12 and the corresponding bounding measurements. A 45-degree (diagonal) line is also shown to provide a point of reference. 
Figure 4: $T_{L}$ Measurements versus Property Predictions

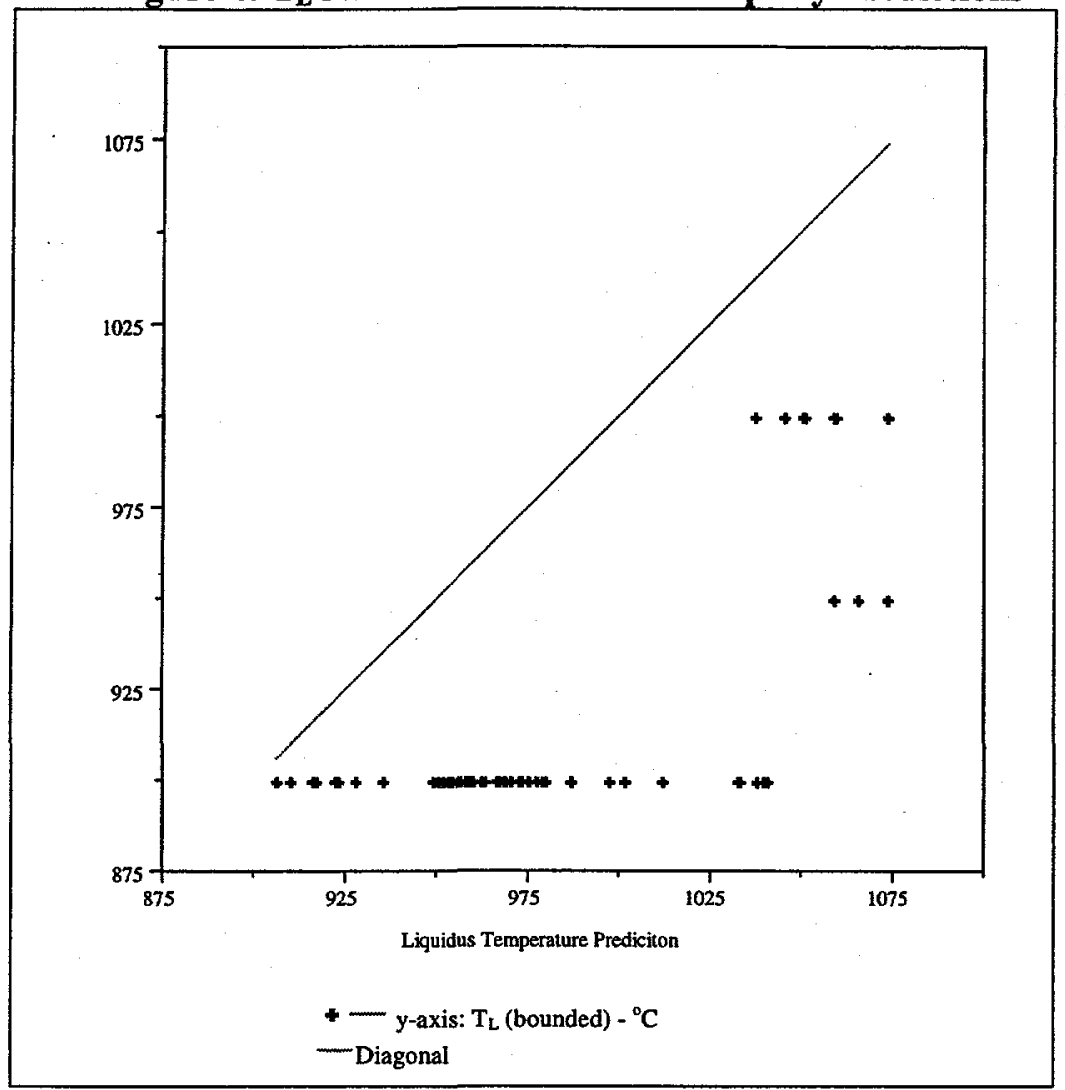

For the $22 \mathrm{wt} \%$ and $26 \mathrm{wt} \%$ Purex glasses, no crystals were detected in the bulk of the glasses at $900^{\circ} \mathrm{C}$. For the $30 \mathrm{wt} \%$ Purex glasses, crystals were evident at temperatures higher than $900^{\circ} \mathrm{C}$, but at $1000^{\circ} \mathrm{C}$ they were below the XRD detection limit. Given the fact that liquidus temperatures were only approximated, the $30 \mathrm{wt} \%$ loading of Purex may be near or at the edge of acceptability for liquidus. For HM glasses, no crystals were detected in the bulk after 24 hours at $900^{\circ} \mathrm{C}$. Thus, these approximate bounding measurements of liquidus temperature suggest that the liquidus constraint $\left(\sim 1025^{\circ} \mathrm{C}[17]\right)$ can be met for these Purex and HM glasses. 


\section{Surface Crystallization}

For liquidus measurements, crystal formation only in the interior or bulk glass region is considered. Therefore, samples submitted for XRD analysis were bulk samples. However, crystals can form at the interface of the glass and the crucible and/or the glass and air. For completeness, the detection of these surface crystals on the top of the glass is provided in Table 4 as a function of temperature.

\section{Table 4. Surface Crystals for the PHA Glasses as a Function of Temperature}

\begin{tabular}{|ccccc|}
\hline \multicolumn{5}{c}{----after the 24 hour heat treatment--- } \\
pha01 & 1150 ${ }^{\circ} \mathrm{C}$ & $1000^{\circ} \mathrm{C}$ & $950^{\circ} \mathrm{C}$ & $900^{\circ} \mathrm{C}$ \\
pha02 & No test & No test & No test & None \\
pha03 & No test & No test & No test & None \\
pha04 & No test & No test & No test & None \\
pha05 & No test & No test & No test & None \\
pha06 & No test & No test & No test & None \\
pha07 & No test & No test & No test & None \\
pha08 & No test & No test & No test & None \\
pha09 & No test & No test & No test & None \\
pha10 & No test & No test & No test & None \\
pha11 & No test & No test & No test & None \\
pha11c & No test & No test & No test & None \\
pha12 & No test & No test & No test & None \\
pha12c & No test & No test & No test & None \\
pha13 & none & none & none & none \\
pha14c & No test & none & none & crystals \\
pha15c & No test & none & No test & crystals \\
pha16 & none & none & none & none \\
pha17c & No test & none & none & crystals \\
pha18c & No test & No test & No test & crystals \\
pha20 & No test & No test & No test & None \\
pha26 & No test & No test & No test & None \\
pha32 & No test & No test & No test & None \\
\hline
\end{tabular}

The crystals observed were located on the top glass surface at the center of the crucible. The chemical composition of the surface crystals was determined by EDS and is consistent with the Trevorite $\left(\mathrm{NiFe}_{2} \mathrm{O}_{4}\right)$ crystal structure. Trevorite has also been observed during previous studies on these types of systems. The chemical composition indicates that other cations are substituted into the crystal structure in small amounts and these include $\mathrm{Ti}, \mathrm{Cr}$, and $\mathrm{Mn}$. 


\section{Phase Separation}

The formation of separate amorphous phases in glass is referred to as amorphous phase separation or inhomogeneity. Crystal formation, as determined by liquidus temperature measurements, on the other hand may indicate a "separation of phases," but reflects crystalline particles within the glass matrix. Amorphous phase separation is to be avoided since the models currently used to predict durability do not apply for glasses predicted to be phase separated. The property acceptance region, or PAR, limit for the homogeneity constraint in the Product Composition Control System (PCCS) is nominally a value of 211 [17]. The limit for the measurement acceptance region, or MAR, for this property will be even higher. In order to pass this constraint, the predicted homogeneity based upon the measured composition must be greater than the MAR value. The homogeneity values calculated using the targeted and measured chemical compositions are all well below the PAR value. These values are provided in Table 5.

Table 5: Homogeneity Property Predictions

\begin{tabular}{|c|c|c|c|}
\hline \multirow[b]{2}{*}{ Glass ID } & \multicolumn{3}{|c|}{$\begin{array}{c}\text { Homogeneity Property Prediction } \\
\text { based on } \\
\text { (Acceptability Requires a Value }>211 \text { ) }\end{array}$} \\
\hline & $\begin{array}{c}\text { Target } \\
\text { Composition }\end{array}$ & $\begin{array}{c}\text { Measured } \\
\text { Composition }\end{array}$ & $\begin{array}{c}\text { Bias-Corrected } \\
\text { Composition }\end{array}$ \\
\hline pha01 & 200.1 & 204.2 & 199.9 \\
\hline pha02 & 199.8 & 199.1 & 196.9 \\
\hline pha03 & 199.4 & 198.6 & 196.6 \\
\hline pha04 & 198.4 & 195.7 & 193.9 \\
\hline pha05 & 198.0 & 193.3 & 191.3 \\
\hline pha06 & 197.7 & 198.7 & 196.6 \\
\hline pha07 & 207.9 & 197.1 & 201.3 \\
\hline pha08 & 207.5 & 202,9 & 207.2 \\
\hline pha09 & 207.2 & 198.3 & 202,4 \\
\hline pha10 & 206.1 & 196.3 & 200.4 \\
\hline phal1 & 205.8 & 200.5 & 204.7 \\
\hline pha11c & 205.8 & 203.7 & 200.5 \\
\hline pha12 & 205.4 & 202.0 & 206.1 \\
\hline pha12c & 205.4 & 205.2 & 202.0 \\
\hline pha13 & 215.6 & 215.7 & 217.5 \\
\hline pha14c & 215.3 & 214.5 & $\mathrm{~N} / \mathrm{A}$ \\
\hline pha15c & 214.9 & 212.6 & N/A \\
\hline pha16 & 213.9 & 221.7 & 223.0 \\
\hline pha17c & 213.5 & 211.1 & 207.1 \\
\hline pha18c & 213.2 & 218.9 & 214.8 \\
\hline pha20 & 201.1 & 199.2 & 197.4 \\
\hline pha26 & 209.1 & 206.0 & 203.5 \\
\hline pha32 & 217.1 & 208.8 & 206.6 \\
\hline
\end{tabular}

Figure 5 provides a plot of the (common logarithm of the) normalized PCT response versus the homogeneity prediction based upon target, measured, and bias-corrected compositions. A vertical line on the $\mathrm{x}$-axis at 211 represents the PAR value for the homogeneity property constraint. The horizontal line at $\sim 1.23$ represents the common logarithm of the normalized PCT response of EA glass. The reference response for $\mathrm{EA}$ is $16.7 \mathrm{~g} / \mathrm{L}$. 


\section{Figure 5: Homogeneity Predictions versus $\log _{10}$ (Normalized PCT Response)}

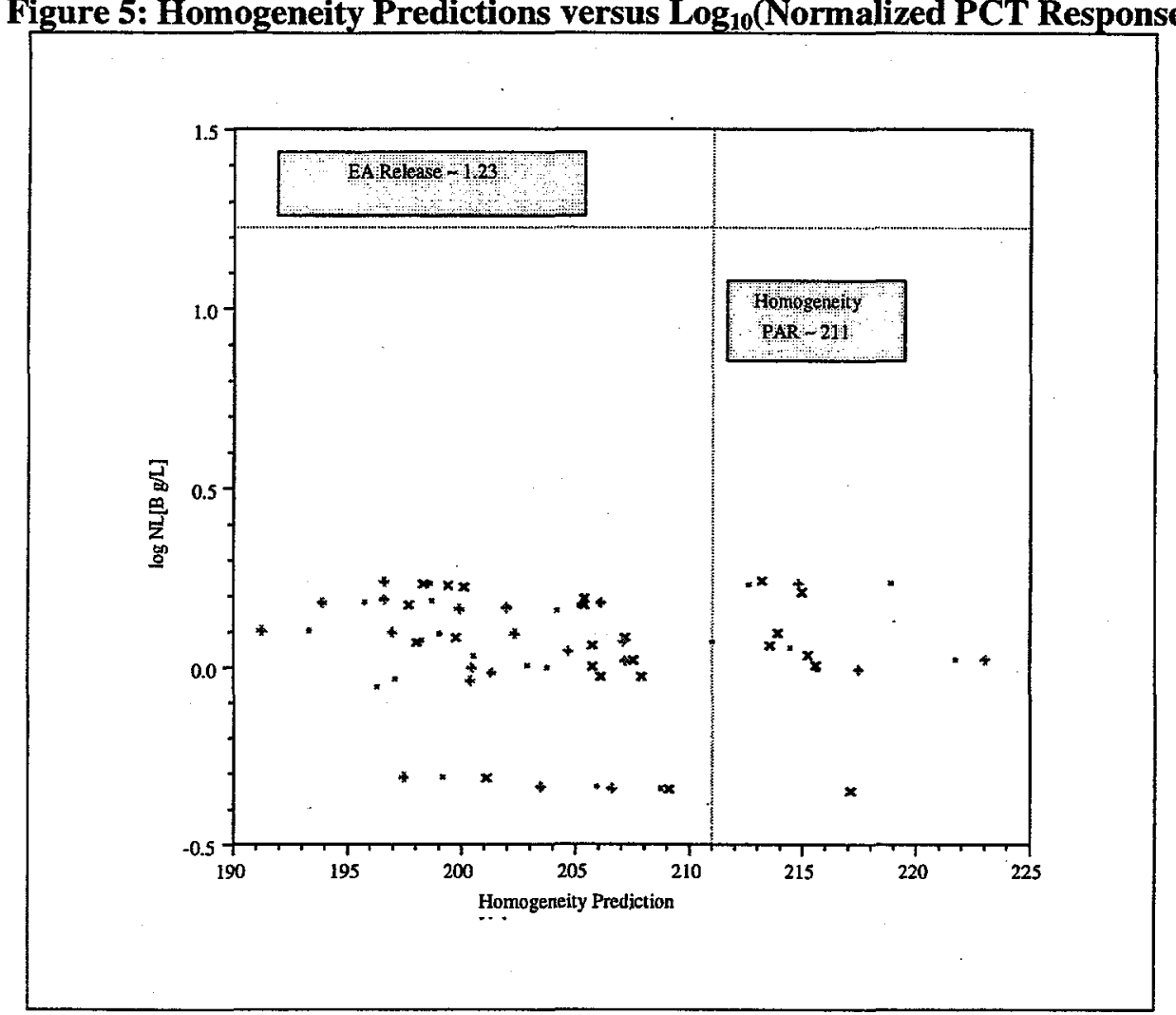

The PCT responses of the PHA glasses made using Purex cover the a wide range of homogeneity predictions and their PCT response all fall within the interval of $0.90 \mathrm{~g} / \mathrm{L}$ to $1.76 \mathrm{~g} / \mathrm{L}$. The PCT responses for the three PHA glasses made using HM sludge fall within the interval of $0.45 \mathrm{~g} / \mathrm{L}$ to 0.50 $\mathrm{g} / \mathrm{L}$.

The homogeneity constraint was developed for glasses that do contain PHA. Therefore, the predictability of phase separation by this model should be applicable. It turns out that 17 of the 23 PHA glasses failed to meet this homogeneity constraint. A significant search for phase separation in these glasses was beyond the scope of work for this task. Therefore, it is unclear whether phase separation has occurred, or would occur upon center-line cooling, in these glasses. On the other hand, all of the PCT results are acceptable and predictable and the results shown in Figure 5 suggest no dependence of durability on the homogeneity value for these glasses.

Further work (including kinetic studies) would be required to resolve this apparent inconsistency. 


\section{CONCLUSIONS}

This report provides a summary of the results obtained for a limited variability study for glasses containing PHA, MST, and either simulated Purex or HM sludge. Twenty glasses containing Purex sludge and three glasses containing HM sludge were fabricated and tested. The fabricated glasses were tested for durability using the PCT and characterized by measuring the melt viscosity and an approximate, bounding liquidus temperature. The current models used by DWPF for predicting durability, viscosity, and liquidus temperature were applied to all 23 glasses. The goal of this work was to identify any major problems from a glass perspective that could potentially preclude the use of higher levels of PHA and MST at DWPF.

The selection of Purex sludge for the majority of the glasses fabricated in this study was based on the knowledge that this sludge type has historically been the most difficult sludge to incorporate into glass. Depleted uranium was introduced into the simulated Purex sludge to better represent the uranium content ( $9 \mathrm{wt} \%$ oxide) of actual sludge.

One of the major concerns for this study was the effect of higher levels of PHA in the glass. The plan for this work was to vary the PHA level from 7 to $13 \mathrm{wt} \%$ oxide, which can be compared to the expected/design basis of 6 to $8 \mathrm{wt} \%$ oxide. Another concern was the potential for higher levels of titanium (from MST) into the glass. The current limit for $\mathrm{TiO}_{2}$ in the DWPF glass is 1 wt $\%$ whereas the scope of this work varied the $\mathrm{TiO}_{2}$ level from 1 to $2 \mathrm{wt} \%$.

Frit 202 was used in this study and was the frit originally designed for coupled operations at DWPF.

As part of this study, the model predictions were made using targeted, measured, and bias-corrected measured compositions of the glasses. For glasses where there were no batching difficulties, it was demonstrated that the results were essentially insensitive to the type of composition used in these models. This provides evidence that the glasses produced were close to the targeted compositions, and that the analytical measurements were of high quality.

Glass Durability. All 23 glasses were very durable as measured by the PCT. The values ranged from 0.90 to $1.76 \mathrm{~g} / \mathrm{L}$ for boron release for the Purex glasses and from 0.45 to $0.50 \mathrm{~g} / \mathrm{L}$ for boron release for the HM glasses. For comparison, the reference Environmental Assessment (EA) glass has a boron rate of $16.7 \mathrm{~g} / \mathrm{L}$.

Model Prediction of Durability. The PCCS durability model predicted values for boron release that were all within the $95 \%$ prediction limits of the model.

Homogeneity. The durability model was developed for glasses that are not phase separated (amorphous) and this is controlled through application of a homogeneity discriminator. The majority of the glasses (17 of the 23 glasses) failed this discrimination model. The PCT results for the glasses of this study (all of which were rapidly quenched) revealed that measured durability is not a function of predicted phase separation based upon the current homogeneity model. Further work (including kinetic studies) is required to resolve this apparent inconsistency.

Liquidus. For this study, the liquidus temperature was bounded by performing 24-hour isothermal holds (as required) for the glass melts at $900^{\circ} \mathrm{C}, 950^{\circ} \mathrm{C}, 1000^{\circ} \mathrm{C}$, and $1050^{\circ} \mathrm{C}$. X-ray diffraction was used to detect crystallization, in this case Trevorite. For the $22 \mathrm{wt} \%$ and $26 \mathrm{wt} \%$ Purex glasses, no crystals were detected in the bulk at $900^{\circ} \mathrm{C}$ or at the top surface of the glasses. For the $30 \mathrm{wt} \%$ Purex glasses, crystals were evident at temperatures higher than $900^{\circ} \mathrm{C}$, but at $1000^{\circ} \mathrm{C}$ they were below the $\mathrm{XRD}$ detection limit. Given the fact that liquidus temperatures were only approximated, the $30 \mathrm{wt} \%$ loading of Purex may be near or at the edge of acceptability for liquidus. A small amount of surface crystallization (after the isothermal hold at $900^{\circ} \mathrm{C}$ ) was evident on the glass surface near the center of the crucible for four of the $30 \mathrm{wt} \%$ Purex glasses. The crystals detected were Trevorite. For HM glasses, no crystals were detected in the bulk or on the surface after 24 hours at $900^{\circ} \mathrm{C}$. 
Viscosity. The melt viscosities for 11 of these 23 glasses were measured and predictions reported at $1150^{\circ} \mathrm{C}$ (nominal temperature of the glass within the DWPF melter). For the Purex containing glasses, the measured viscosities were within the DWPF range of 20 to 100 poise for the $22 \mathrm{wt} \%$ and $26 \mathrm{wt} \%$ Purex glasses. However, the $30 \mathrm{wt} \%$ Purex glasses had viscosities that were very near the lower limit of 20 poise, and consequently, may not be acceptable from an operations perspective. Although the HM sludge glass measured (10wt\% PHA) had a viscosity of $~ 90$ poise, the HM glasses at $7 \mathrm{wt} \%$ PHA are predicted to be higher than the 100 poise limit for DWPF.

Limitations. All of the conclusions are provided based on the scope of the current work. One limitation of this scope, based upon schedule and budget, was the absence of any investigation of kinetic effects. Thus, one can not rule out that amorphous phase separation occurs with centerline cooling, for example. A second limitation was the restriction on independent variation of chemical constituents. In a major variability study, ranges are established for each element, and a statistically designed set of glasses identified which not only covers a larger region of compositional space, but also provides the potential for revealing trends in the properties over linear variations of elemental concentrations. A third limitation was that only approximate measurements of the liquidus temperatures were made. A fourth limitation was that a thorough search (beyond scanning electron microscopy) for phase separation was not conducted. This type of investigation requires considerable efforts using transmission electron microscopy (TEM) and other high-resolution techniques. Finally, although the strategy was that HM and Purex containing glasses would cover the extremes, no Blend sludge glasses were fabricated to verify this. 


\section{REFERENCES}

[1] Elder, H. H., "Technical Task Request: DWPF Waste Qualification - DWPF Coupled Operation Chemistry," HLW-SDT-TTR-99-07.0, February 2, 1999.

[2] Harbour, J. R. and T. B. Edwards, "Technical Task and QA Plan: DWPF Coupled Operation Chemistry-PHA Glass Testing," WSRC-RP-99-00218, Revision 1, April 23, 1999.

[3] Edwards, T. B., J. R. Harbour, R. J. Workman, "Composition and Property Measurement for PHA Phase 1 Glasses (U)," WSRC-TR-99-00262, August 4, 1999.

[4] Edwards, T. B., J. R. Harbour, R. J. Workman, "Composition and Property Measurement for PHA Phase 2 Glasses (U)," WSRC-TR-99-00290, August 18, 1999.

[5] Edwards, T. B., J. R. Harbour, R. J. Workman, "Composition and Property Measurement for PHA Phase 3 Glasses (U)," WSRC-TR-99-00292, August 18, 1999.

[6] Edwards, T. B., J. R. Harbour, R. J. Workman, "Composition and Property Measurement for CST Phase 4 Glasses (U)," WSRC-TR-99-00294, August 18, 1999.

[7] ASTM C1285-97, "Standard Test Methods for Determining Chemical Durability of Nuclear Waste Glasses: The Product Consistency Test (PCT)," 1997.

[8] Harbour, J. R. and T. B. Edwards, "Analytical Study Plan-CST: DWPF Waste QualificationCST in Glass," WSRC-RP-99-00316, Revision 0, April 14, 1999.

[9] Schumacher, R. F. and D. K. Peeler, "Establishment of Harrop, High-Temperature Viscometer," WSRC-RP-98-00737, Revision 0, September 1998.

[10] Schumacher, R. F., R. J. Workman, J. R. Harbour, and T. B. Edwards, "Measurements of DWPF Glass Viscosity - Interim Report," WSRC-RP-99-00350, Revision 0, May 5, 1999.

[11] Edwards, T. B., J. R. Harbour, R. J. Workman, "Composition and Property Measurement for CST Phase 1 Glasses (U)," WSRC-TR-99-00245, July 27, 1999.

[12] Edwards, T. B., J. R. Harbour, R. J. Workman, "Composition and Property Measurement for CST Phase 2 Glasses (U)," WSRC-TR-99-00289, August 18, 1999.

[13] Edwards, T. B., J. R. Harbour, R. J. Workman, "Composition and Property Measurement for CST Phase 3 Glasses (U)," WSRC-TR-99-00291, August 18, 1999.

[14] Edwards, T. B., J. R. Harbour, R. J. Workman, "Composition and Property Measurement for CST Phase 4 Glasses (U),"WSRC-TR-99-00293, August 18, 1999.

[15] Jantzen, C. M., J. B. Pickett, K. G. Brown, T. B. Edwards, and D. C. Beam, "Process/Product Models for the Defense Waste Processing Facility (DWPF): Part I. Predicting Glass Durability from Composition Using a Thermodynamic Hydration Energy Reaction Model (THERMO) (U)," WSRC-TR-93-672, Rev. 1, September 28, 1995.

[16] Cicero, C. A., S. L. Marra, and M. K. Andrews, "Phase Stability Determinations of DWPF Waste Glasses (U)," WSRC-TR-93-227, Revision 0, 1993.

[17] Brown, K. G. and R. L. Postles, "SME Acceptability Determination for DWPF Process Control (U)," WSRC-TR-95-0364, Revision 3, February 21, 1996. 
WSRC-TR-99-00332

Revision 0

This page intentionally left blank. 
WSRC-TR-99-00332

Revision 0

Appendix:

Supplemental Tables and Exhibits 
WSRC-TR-99-00332

Revision 0

Table A.1: Target Oxide Compositions (in weight percents, wt\%'s) of the CST Glasses

\begin{tabular}{|c|c|c|c|c|c|c|c|c|c|c|c|c|c|c|c|c|}
\hline Purex & & & & & is & & & & & & & & & & & \\
\hline Sludge & MST & CST & Frit & ID & $\mathrm{Al}_{2} \mathrm{O}_{3}$ & $\mathrm{~B}_{2} \mathrm{O}_{3}$ & $\mathbf{B a O}$ & $\mathrm{CaO}$ & $\mathrm{Cr}_{2} \mathrm{O}_{3}$ & $\mathrm{CuO}$ & $\mathrm{Fe}_{2} \mathrm{O}_{3}$ & $\mathbf{K}_{2} \mathrm{O}$ & $\mathrm{Li}_{2} \mathrm{O}$ & MgO & $\mathrm{MnO}$ & $\mathrm{Na}_{2} \mathrm{O}$ \\
\hline 22 & 1.250 & 3 & 73.750 & $\operatorname{cst} 01$ & 2.556 & 8.223 & 0.084 & 0.841 & 0.106 & 0.047 & 9.843 & 0.092 & 4.750 & 0.067 & 1.727 & 8.848 \\
\hline 22 & 1.250 & 6 & 70.750 & cst02 & 2.539 & 7.889 & 0.084 & 0.841 & 0.106 & 0.047 & 9.843 & 0.092 & 4.556 & 0.067 & 1.727 & 8.760 \\
\hline 22 & 2.500 & 3 & 72.500 & cst04 & 2.549 & 8.084 & 0.084 & 0.841 & 0.106 & 0.047 & 9.843 & 0.092 & 4.669 & 0.067 & 1.727 & 8.900 \\
\hline 22 & 2.500 & 6 & 69.500 & $\operatorname{cst} 05$ & 2.531 & 7.749 & 0.084 & 0.841 & 0.106 & 0.047 & 9.843 & 0.092 & 4.476 & 0.067 & 1.727 & 8.812 \\
\hline 22 & 2.500 & 9 & 66.500 & cst06 & 2.514 & 7.415 & 0.084 & 0.841 & 0.106 & 0.047 & 9.843 & 0.092 & 4.283 & 0.067 & 1.727 & 8.725 \\
\hline 26 & 1.250 & 3 & 69.750 & cst07 & 2.918 & 7.777 & 0.099 & 0.994 & 0.125 & 0.056 & 11.633 & 0.109 & 4.492 & 0.079 & 2.041 & 9.022 \\
\hline 26 & 1.250 & 6 & 66.750 & cst08 & 2.901 & 7.443 & 0.099 & 0.994 & 0.125 & 0.056 & 11.633 & 0.109 & 4.299 & 0.079 & 2.041 & 8.934 \\
\hline 26 & 1.250 & 9 & 63.750 & cst09 & 2.883 & 7.108 & 0.099 & 0.994 & 0.125 & 0.056 & 11.633 & 0.109 & 4.106 & 0.079 & 2.041 & 8.846 \\
\hline 26 & 2.500 & 3 & 68.500 & cst10 & 2.911 & 7.638 & 0.099 & 0.994 & 0.125 & 0.056 & 11.633 & 0.109 & 4.411 & 0.079 & 2.041 & 9.074 \\
\hline 26 & 2.500 & 6 & 65.500 & cst11 & 2.893 & 7.303 & 0.099 & 0.994 & 0.125 & 0.056 & 11.633 & 0.109 & 4.218 & 0.079 & 2.041 & 8.986 \\
\hline 26 & 2.500 & 9 & 62.500 & cst12 & 2.876 & 6.969 & 0.099 & 0.994 & 0.125 & 0.056 & 11.633 & 0.109 & 4.025 & 0.079 & 2.041 & .898 \\
\hline 30 & 1.250 & 3 & 65.750 & cst13 & 3.281 & 7.331 & 0.114 & 1.146 & 0.144 & 0.064 & 13.423 & 0.126 & 4.234 & 0.091 & 2.355 & 9.195 \\
\hline 30 & 1.250 & 6 & 62.750 & $\operatorname{cst14}$ & 3.263 & 6.997 & 0.114 & 1.146 & 0.144 & 0.064 & 13.423 & 0.126 & 4.041 & 0.091 & 2.355 & 9.107 \\
\hline 30 & 1.250 & 9 & 59.750 & cst15 & 3.245 & 6.662 & 0.114 & 1.146 & 0.144 & 0.064 & 13.423 & 0.126 & 3.848 & 0.091 & 2.355 & 9.019 \\
\hline 30 & 2.500 & 6 & 61.500 & $\operatorname{cst17}$ & 3.255 & 6.857 & 0.114 & 1.146 & 0.144 & 0.064 & 13.423 & 0.126 & 3.961 & 0.091 & 2.355 & 9.159 \\
\hline 30 & 2.500 & 9 & 58.500 & cstl 8 & 3.238 & 6.523 & 0.114 & 1.146 & 0.144 & 0.064 & 13.423 & 0.126 & 3.767 & 0.091 & 2.355 & 9.071 \\
\hline Purex & & & & Glass & & & & & & & & & & & & \\
\hline Sludge & MST & CST & Frit & ID & $\mathbf{N b}_{2} \mathbf{O}_{5}$ & NiO & $\mathbf{P}_{2} \mathbf{O}_{5}$ & $\mathbf{P b O}$ & $\mathrm{SiO}_{2}$ & $\mathrm{TiO}_{2}$ & $\mathbf{U}_{3} \mathbf{O}_{8}$ & ZnO & $\mathrm{ZrO}_{2}$ & & $\mathrm{Cl}^{-}$ & $\left.\mathrm{O}_{4}\right)^{\circ}$ \\
\hline 22 & 1.250 & 3 & 73.750 & $\operatorname{cst} 01$ & 0.660 & 0.930 & 0.030 & 0.096 & 55.760 & 2.149 & 2.003 & 0.086 & 0.619 & 0.032 & 0.240 & 0.173 \\
\hline 22 & 1.250 & 6 & 70.750 & $\operatorname{cst} 02$ & 1.320 & 0.930 & 0.030 & 0.096 & 54.144 & 3.199 & 2.003 & 0.086 & 1.129 & 0.032 & 0.240 & 0.173 \\
\hline 22 & 1.250 & 9 & 67.750 & cst03 & 1.980 & 0.930 & 0.030 & 0.096 & 52.528 & 4.249 & 2.003 & 0.086 & 1.639 & 0.032 & 0.240 & 0.173 \\
\hline 22 & 2.500 & 3 & 72.500 & cst04 & 0.660 & 0.930 & 0.030 & 0.096 & 54.837 & 3.247 & 2.003 & 0.086 & 0.619 & 0.032 & 0.240 & 0.173 \\
\hline 22 & 2.500 & 6 & 69.500 & $\operatorname{cst05}$ & 1.320 & 0.930 & 0.030 & 0.096 & 53.221 & 4.297 & 2.003 & 0.086 & 1.129 & 0.032 & 0.240 & 0.173 \\
\hline 22 & 2.500 & 9 & 66.500 & $\operatorname{cst06}$ & 1.980 & 0.930 & 0.030 & 0.096 & 51.604 & 5.347 & 2.003 & 0.086 & 1.639 & 0.032 & 0.240 & 0.173 \\
\hline 26 & 1.250 & 3 & 69.750 & $\operatorname{cst} 07$ & 0.660 & 1.099 & 0.036 & 0.114 & 52.928 & 2.149 & 2.367 & 0.102 & 0.639 & 0.038 & 0.283 & 0.205 \\
\hline 26 & 1.250 & 6 & 66.750 & cst08 & 1.320 & 1.099 & 0.036 & 0.114 & 51.311 & 3.199 & 2.367 & 0.102 & 1.149 & 0.038 & 0.283 & 0.205 \\
\hline 26 & 1.250 & 9 & 63.750 & cst09 & 1.980 & 1.099 & 0.036 & 0.114 & 49.695 & 4.249 & 2.367 & 0.102 & 1.659 & 0.038 & 0.283 & 0.205 \\
\hline 26 & 2.500 & 3 & 68.500 & $\operatorname{cst} 10$ & 0.660 & 1.099 & 0.036 & 0.114 & 52.004 & 3.247 & 2.367 & 0.102 & 0.639 & 0.038 & 0.283 & 0.205 \\
\hline 26 & 2.500 & 6 & 65.500 & cst11 & 1.320 & 1.099 & 0.036 & 0.114 & 50.388 & 4.297 & 2.367 & 0.102 & 1.149 & 0.038 & 0.283 & 0.205 \\
\hline 26 & 2.500 & 9 & 62.500 & $\operatorname{cst} 12$ & 1.980 & 1.099 & 0.036 & 0.114 & 48.771 & 5.347 & 2.367 & 0.102 & 1.659 & 0.038 & 0.283 & 0.205 \\
\hline 30 & 1.250 & 9 & 59.750 & cst15 & 1.980 & 1.268 & 0.041 & 0.132 & 46.862 & 4.249 & 2.731 & 0.118 & 1.679 & 0.043 & 0.327 & 0.236 \\
\hline 30 & 2.500 & 3 & 64.500 & cst16 & 0.660 & 1.268 & 0.041 & 0.132 & 49.172 & 3.247 & 2.731 & 0.118 & 0.659 & 0.043 & 0.327 & 0.236 \\
\hline 30 & 2.500 & 6 & 61.500 & cst17 & 1.320 & 1.268 & 0.041 & 0.132 & 47.555 & 4.297 & 2.731 & 0.118 & 1.169 & 0.043 & 0.327 & 0.236 \\
\hline 30 & 2.500 & 9 & 58.500 & cst18 & 1.980 & 1.268 & 0.041 & 0.132 & 45.939 & 5.347 & 2.731 & 0.118 & 1.679 & 0.043 & 0.327 & 0.236 \\
\hline
\end{tabular}


WSRC-TR-99-00332

Revision 0

Table A.2: Target Compositions of PHA Phase 4 HM Glasses

\begin{tabular}{|cccc|cccc|}
\hline Glass ID & pha20 & pha26 & pha32 & Glass ID & pha20 & pha26 & pha32 \\
Sludge & 22 & 26 & 30 & Sludge & 22 & 26 & 30 \\
$\mathrm{MST}$ & 1.25 & 1.25 & 1.25 & $\mathrm{MST}$ & 1.25 & 1.25 & 1.25 \\
$\mathrm{PHA}$ & 10 & 10 & 10 & PHA & 10 & 10 & 10 \\
$\mathrm{Frit} \mathrm{202}$ & 66.75 & 62.75 & 58.75 & Frit 202 & 66.75 & 62.75 & 58.75 \\
\hline $\mathrm{Al}_{2} \mathrm{O}_{3}$ & 6.046 & 7.048 & 8.051 & $\mathrm{NiO}$ & 0.336 & 0.397 & 0.458 \\
$\mathrm{~B}_{2} \mathrm{O}_{3}$ & 8.803 & 8.488 & 8.174 & $\mathrm{P}_{2} \mathrm{O}_{5}$ & 0.032 & 0.038 & 0.044 \\
$\mathrm{BaO}$ & 0.045 & 0.053 & 0.061 & $\mathrm{PbO}$ & 0.053 & 0.063 & 0.073 \\
$\mathrm{CaO}$ & 0.496 & 0.562 & 0.628 & $\mathrm{SiO}_{2}$ & 54.086 & 51.656 & 49.226 \\
$\mathrm{Cr}_{2} \mathrm{O}_{3}$ & 0.073 & 0.086 & 0.099 & $\mathrm{TiO}_{2}$ & 1.127 & 1.125 & 1.123 \\
$\mathrm{CuO}$ & 0.761 & 0.764 & 0.767 & $\mathrm{U}_{3} \mathrm{O}_{8}$ & 0.677 & 0.800 & 0.923 \\
$\mathrm{Fe}_{2} \mathrm{O}_{3}$ & 6.363 & 7.507 & 8.652 & $\mathrm{ZnO}$ & 0.014 & 0.016 & 0.019 \\
$\mathrm{~K}_{2} \mathrm{O}$ & 4.723 & 4.736 & 4.749 & $\mathrm{ZrO}_{2}$ & 0.119 & 0.141 & 0.163 \\
$\mathrm{Li} \mathrm{O}$ & 4.579 & 4.305 & 4.030 & $\mathrm{~F}-$ & 0.037 & 0.044 & 0.051 \\
$\mathrm{MgO}_{\mathrm{MnO}}$ & 1.463 & 1.409 & 1.355 & $\mathrm{Cl}-$ & 0.124 & 0.147 & 0.169 \\
$\mathrm{Na}_{2} \mathrm{O}$ & 1.955 & 2.311 & 2.667 & $\left(\mathrm{SO}_{4}\right)-$ & 0.127 & 0.150 & 0.173 \\
\hline
\end{tabular}


WSRC-TR-99-00332

Revision 0

Table A.3: Target, Measured and Bias-Corrected Compositions (in wt \%) for the CST Glasses

\begin{tabular}{|c|c|c|c|c|c|c|c|c|c|}
\hline & & hase I-ph & $\begin{array}{l}07 \\
\text { Measured }\end{array}$ & & hase I-phe & $\begin{array}{l}08 \\
\text { Measured }\end{array}$ & & hase I-ph & $\begin{array}{l}09 \\
\text { Measured }\end{array}$ \\
\hline & Target & Measured & Bias-cor. & Target & Measured & Bias-cor. & Target & Measured & Bias-cor. \\
\hline $\mathbf{A l}_{2} \mathbf{O}_{3}$ & 2.901 & 2.650 & 2.758 & 2.883 & 2.711 & 2.822 & 2.865 & 2.707 & 2.817 \\
\hline $\mathrm{B}_{2} \mathrm{O}_{3}$ & 7.660 & 7.688 & 7.403 & 8.488 & 8.766 & 8.435 & 9.317 & 9.410 & 9.068 \\
\hline $\mathrm{CaO}$ & 1.092 & 1.119 & 1.051 & 1.088 & 1.129 & 1.060 & 1.083 & 1.099 & 1.032 \\
\hline $\mathrm{Cr}_{2} \mathrm{O}_{3}$ & 0.125 & 0.121 & 0.129 & 0.125 & 0.113 & 0.120 & 0.125 & 0.113 & 0.121 \\
\hline $\mathrm{CuO}$ & 0.576 & 0.492 & 0.514 & 0.800 & 0.693 & 0.725 & 1.023 & 0.761 & 0.795 \\
\hline $\mathrm{Fe}_{2} \mathrm{O}_{3}$ & 11.685 & 10.308 & 10.855 & 11.683 & 10.626 & 11.201 & 11.681 & 9.951 & 10.475 \\
\hline $\mathrm{K}_{2} \mathrm{O}$ & 3.365 & 3.084 & 3.071 & 4.745 & 4.352 & 4.335 & 6.125 & 5.294 & 5.273 \\
\hline $\mathbf{L i}_{2} \mathrm{O}$ & 4.510 & 4.236 & 4.468 & 4.305 & 4.080 & 4.304 & 4.099 & 4.037 & 4.259 \\
\hline MgO & 1.381 & 1.382 & 1.417 & 1.322 & 1.331 & 1.365 & 1.262 & 1.272 & 1.304 \\
\hline MnO & 2.041 & 1.863 & 1.938 & 2.041 & 1.875 & 1.950 & 2.041 & 1.905 & 1.981 \\
\hline $\mathrm{Na}_{2} \mathrm{O}$ & 8.116 & 8.071 & 7.910 & 8.264 & 8.391 & 8.222 & 8.412 & 8.374 & 8.206 \\
\hline $\mathrm{NiO}$ & 1.099 & 0.866 & 0.902 & 1.099 & 0.861 & 0.897 & 1.099 & 0.857 & 0.893 \\
\hline $\mathbf{S i O}_{2}$ & 50.766 & 50.274 & 51.040 & 48.486 & 50.006 & 50.778 & 46.206 & 48.081 & 48.940 \\
\hline $\mathrm{TiO}_{2}$ & 1.126 & 0.691 & 0.689 & 1.125 & 0.698 & 0.697 & 1.124 & 0.707 & 0.705 \\
\hline $\mathbf{U}_{3} \mathbf{O}_{8}$ & 2.367 & 2.633 & 2.633 & 2.367 & 2.161 & 2.161 & 2.367 & 2.565 & 2.565 \\
\hline $\mathrm{ZrO}_{2}$ & 0.129 & 0.128 & 0.137 & 0.129 & 0.126 & 0.134 & 0.129 & 0.132 & 0.140 \\
\hline Sum of Oxides & 98.939 & 95.647 & 96.958 & 98.950 & 97.963 & 99.250 & 98.958 & 97.306 & 98.618 \\
\hline & & hase I-ph & 10 & & hase 1-ph & 11 & & hase 1-ph & 12 \\
\hline & Target & Measured & Bias-cor. & Target & Measured & Bias-cor. & Target & Measured & Bias-cor. \\
\hline $\mathrm{Al}_{2} \mathrm{O}_{3}$ & 2.894 & 2.636 & 2.743 & 2.876 & 2.664 & 2.773 & 2.858 & 2.626 & 2.733 \\
\hline $\mathrm{B}_{2} \mathrm{O}_{3}$ & 7.561 & 7.985 & 7.693 & 8.390 & 8.967 & 8.646 & 9.219 & 9.724 & 9.375 \\
\hline $\mathrm{CaO}$ & 1.090 & 1.109 & 1.043 & 1.086 & 1.102 & 1.036 & 1.081 & 1.114 & 1.047 \\
\hline $\mathrm{Cr}_{2} \mathrm{O}_{3}$ & 0.125 & 0.113 & 0.121 & 0.125 & 0.117 & 0.124 & 0.125 & 0.111 & 0.119 \\
\hline $\mathrm{CuO}$ & 0.576 & 0.501 & 0.523 & 0.800 & 0.676 & 0.707 & 1.023 & 0.818 & 0.855 \\
\hline $\mathrm{Fe}_{2} \mathrm{O}_{3}$ & 11.684 & 9.701 & 10.205 & 11.682 & 9.879 & 10.403 & 11.680 & 10.344 & 10.880 \\
\hline $\mathrm{K}_{2} \mathrm{O}$ & 3.365 & 3.123 & 3.111 & 4.745 & 4.255 & 4.239 & 6.125 & 5.514 & 5.491 \\
\hline $\mathbf{L i}_{2} \mathbf{O}$ & 4.425 & 4.295 & 4.533 & 4.219 & 4.091 & 4.315 & 4.013 & 3.929 & 4.145 \\
\hline MgO & 1.356 & 1.337 & 1.370 & 1.297 & 1.285 & 1.317 & 1.237 & 1.230 & 1.261 \\
\hline Mno & 2.041 & 1.853 & 1.928 & 2.041 & 1.840 & 1.914 & 2.041 & 1.837 & 1.910 \\
\hline $\mathrm{Na}_{2} \mathrm{O}$ & 8.191 & 8.341 & 8.178 & 8.339 & 8.432 & 8.266 & 8.487 & 8.543 & 8.373 \\
\hline $\mathrm{NiO}$ & 1.099 & 0.838 & 0.873 & 1.099 & 0.861 & 0.898 & 1.099 & 0.849 & 0.885 \\
\hline $\mathrm{SiO}_{2}$ & 49.816 & 51.343 & 52.180 & 47.536 & 51.236 & 52.113 & 45.256 & 48.669 & 49.502 \\
\hline $\mathrm{TiO}_{2}$ & 2.224 & 1.369 & 1.365 & 2.223 & 1.337 & 1.334 & 2.222 & 1.350 & 1.346 \\
\hline $\mathrm{U}_{3} \mathrm{O}_{8}$ & 2.367 & 2.409 & 2.409 & 2.367 & 2.462 & 2.462 & 2.367 & 2.456 & 2.456 \\
\hline $\mathrm{ZrO}_{2}$ & 0.129 & 0.126 & 0.134 & 0.129 & 0.122 & 0.130 & 0.129 & 0.122 & 0.129 \\
\hline Sum of Oxides & 98.943 & 97.171 & 98.504 & 98.954 & 99.415 & 100.764 & 98.962 & 99.327 & 100.600 \\
\hline & & hase 2-ph & & & hase 2-phe & & & hase 2-ph & \\
\hline & & & Measured & & & Measure & & & ared \\
\hline & Target & Measured & Bias-cor. & Target & Measured & Bias-cor. & Target & Measured & Bias-cor. \\
\hline $\mathbf{A l}_{2} \mathbf{O}_{3}$ & 3.263 & 3.246 & 3.725 & 3.245 & 3.120 & 3.580 & 3.227 & 3.116 & 3.576 \\
\hline $\mathrm{B}_{2} \mathrm{O}_{3}$ & 7.345 & 7.492 & 7.498 & 8.174 & 10.060 & 10.069 & 9.003 & 11.647 & 11.657 \\
\hline $\mathrm{CaO}$ & 1.239 & 1.357 & 1.196 & 1.234 & 1.272 & 1.132 & 1.230 & 1.371 & 1.204 \\
\hline $\mathrm{Cr}_{2} \mathrm{O}_{3}$ & 0.144 & 0.152 & 0.149 & 0.144 & 0.146 & 0.143 & 0.144 & 0.153 & 0.150 \\
\hline $\mathrm{CuO}$ & 0.585 & 0.573 & 0.575 & 0.808 & 0.739 & 0.741 & 1.031 & 0.959 & 0.962 \\
\hline $\mathrm{Fe}_{2} \mathrm{O}_{3}$ & 13.472 & 13.615 & 13.236 & 13.470 & 13.851 & 13.466 & 13.467 & 14.684 & 14.275 \\
\hline $\mathrm{K}_{2} \mathrm{O}$ & 3.380 & 3.470 & 3.694 & 4.760 & 4.150 & 4.417 & 6.140 & 4.607 & 4.905 \\
\hline $\mathbf{L i}_{2} \mathbf{O}$ & 4.236 & 4.214 & 4.171 & 4.030 & 4.006 & 3.964 & 3.824 & 3.766 & 3.727 \\
\hline MgO & 1.314 & 1.284 & 1.570 & 1.255 & 1.228 & 1.502 & 1.195 & 1.145 & 1.401 \\
\hline MnO & 2.355 & 2.272 & 2.359 & 2.355 & 2.176 & 2.259 & 2.355 & 2.156 & 2.239 \\
\hline $\mathrm{Na}_{2} \mathrm{O}$ & 8.363 & 8.342 & 8.673 & 8.511 & 9.175 & 9.539 & 8.659 & 9.959 & 10.354 \\
\hline $\mathrm{NiO}$ & 1.268 & 1.142 & 1.089 & 1.268 & 1.109 & 1.057 & 1.268 & 1.134 & 1.081 \\
\hline $\mathrm{SiO}_{2}$ & 47.849 & 46.844 & 47.619 & 45.569 & 45.191 & 45.916 & 43.289 & 41.318 & 42.011 \\
\hline $\mathrm{TiO}_{2}$ & 1.125 & 0.738 & 0.736 & 1.123 & 0.742 & 0.740 & 1.122 & 0.721 & 0.719 \\
\hline $\mathrm{U}_{3} \mathrm{O}_{\mathrm{B}}$ & 2.731 & 2.792 & 2.792 & 2.731 & 2.921 & 2.921 & 2.731 & 1.988 & 1.988 \\
\hline $\mathrm{ZrO}_{2}$ & 0.149 & 0.182 & 0.194 & 0.149 & 0.171 & 0.182 & 0.149 & 0.183 & 0.195 \\
\hline Sum of Oxides & 98.818 & 97.792 & 99.353 & 98,826 & 100.131 & 101.702 & 98.834 & 98.990 & 100.526 \\
\hline
\end{tabular}


WSRC-TR-99-00332

Revision 0

Table A.3: Target, Measured, and Bias-Corrected Compositions (in wt\%) for the CST Glasses (continued)

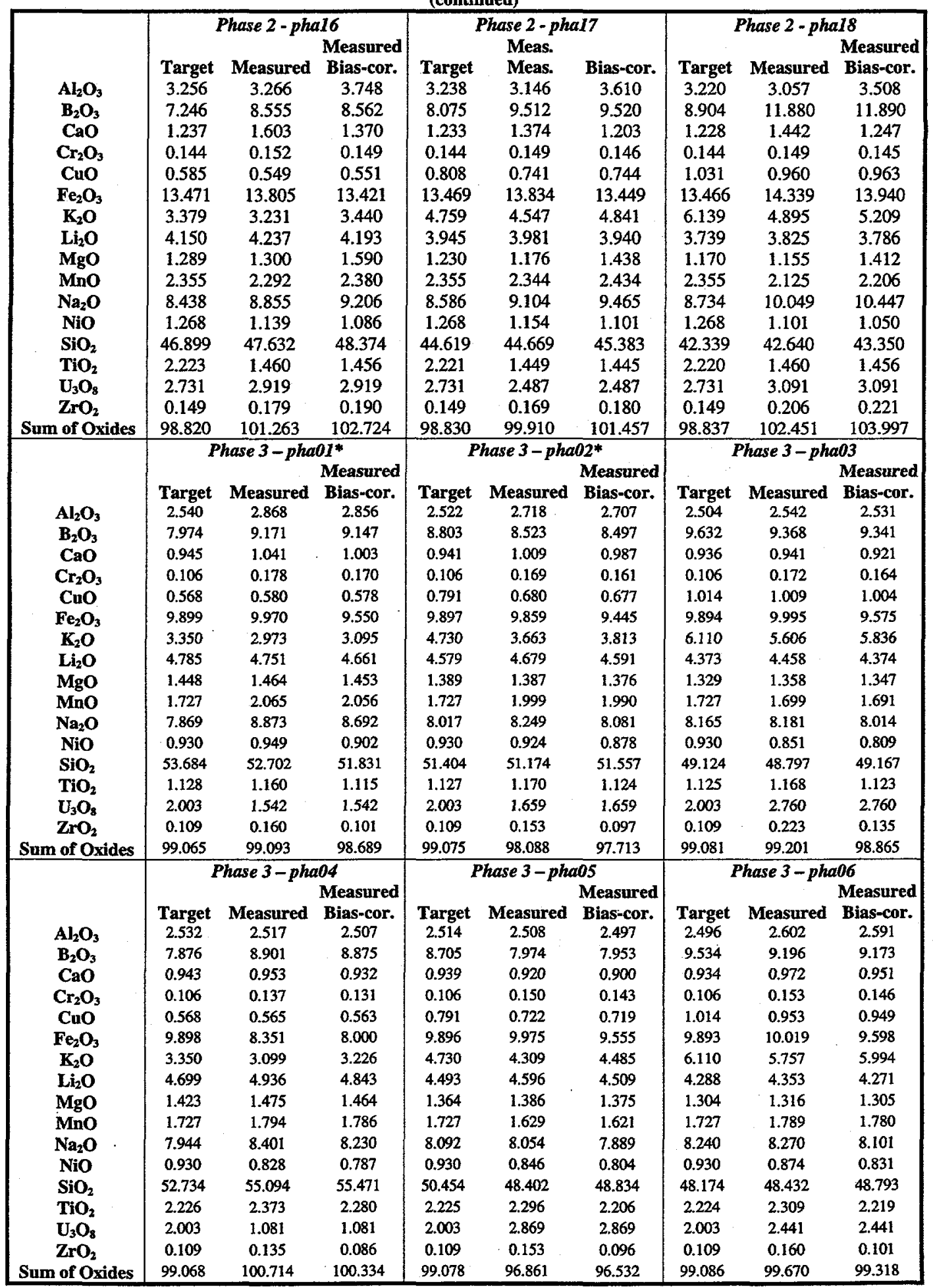


Table A.3: Target, Measured and Bias-Corrected Compositions (in wt \%) for the CST Glasses

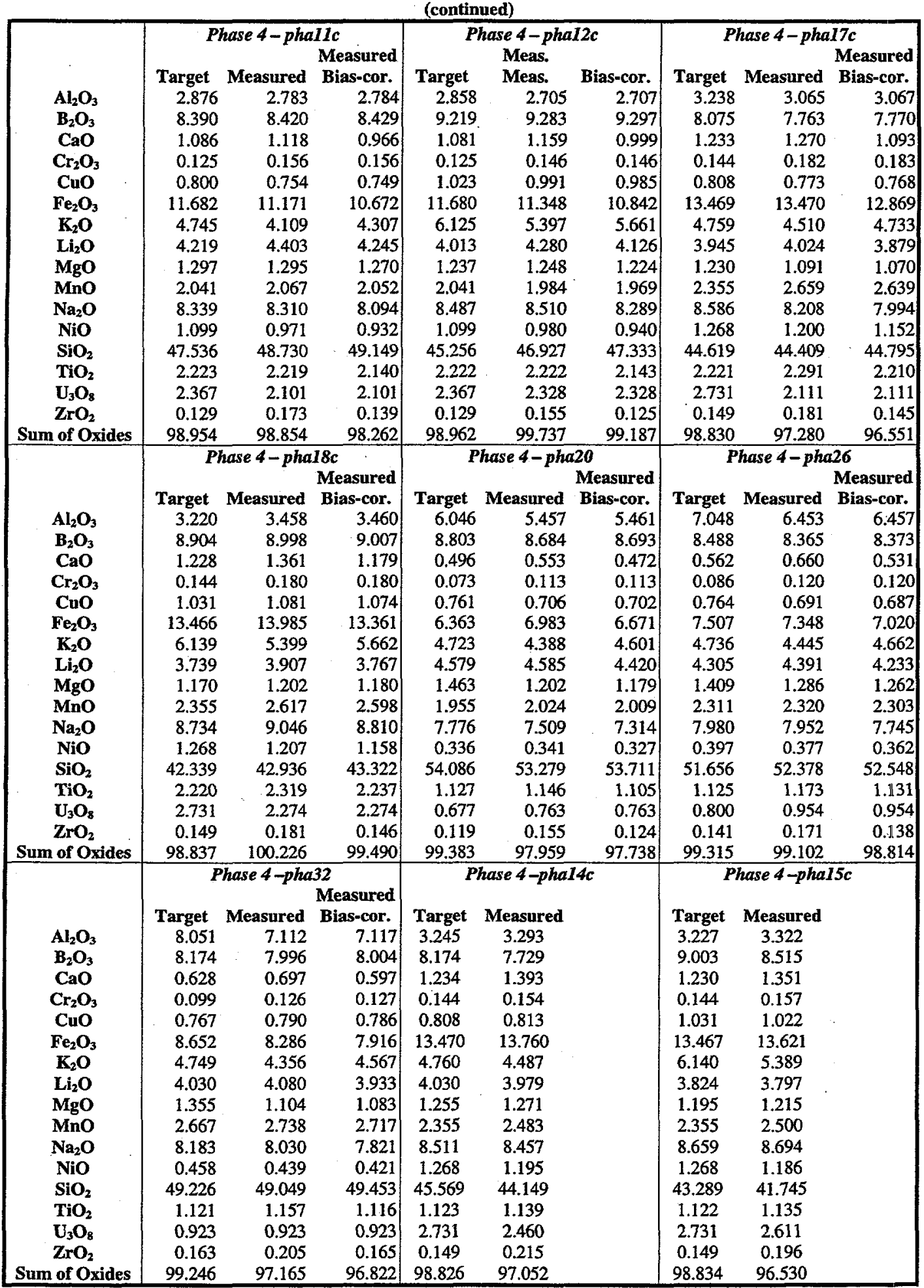


WSRC-TR-99-00332

Revision 0

Table A.4: Normalized PCTs for the CST Glasses

\begin{tabular}{|c|c|c|c|c|c|c|c|c|c|}
\hline Glass ID & Composition & $\begin{array}{c}\log N L \\
{[B(g / L)]}\end{array}$ & $\begin{array}{c}\log N L \\
{[S i(g / L)]}\end{array}$ & $\begin{array}{c}\log \mathrm{NL} \\
{[\mathrm{Na}(\mathrm{g} / \mathrm{L})]}\end{array}$ & $\begin{array}{c}\log \mathrm{NL} \\
{[\mathrm{Li}(\mathrm{g} / \mathrm{L})]}\end{array}$ & $B(g / L)$ & $\mathrm{Si}(\mathrm{g} / \mathrm{L})$ & $\mathrm{Na}(\mathrm{g} / \mathrm{L})$ & $L \mathrm{di}(g / L)$ \\
\hline EA & Phase 1 & 1.24851 & 0.61951 & 1.15692 & 0.99969 & 17.72 & 4.16 & 14.35 & 9.99 \\
\hline EA & Phase 2 & 1.27261 & 0.61353 & 1.17131 & 1.02046 & 18.73 & 4.11 & 14.84 & 10.48 \\
\hline EA & Phases 3-4 & 1.28207 & 0.63353 & 1.18838 & 1.04022 & 19.15 & 4.30 & 15.43 & 10.97 \\
\hline ARM & Phase 1 & -0.22197 & -0.50764 & -0.22580 & -0.16767 & 0.60 & 0.31 & 0.59 & 0.68 \\
\hline ARM & Phase 2 & -0.27166 & -0.55545 & -0.26983 & -0.20863 & 0.53 & 0.28 & 0.54 & 0.62 \\
\hline ARM & Phases 3-4 & -0.29085 & -0.54854 & -0.27396 & -0.21652 & 0.51 & 0.28 & 0.53 & 0.61 \\
\hline pha01 & measured & 0.16802 & -0.17747 & 0.11093 & 0.13608 & 1.47 & 0.66 & 1.29 & 1.37 \\
\hline pha01 & measured bc & 0.16916 & -0.17023 & 0.11988 & 0.14439 & 1.48 & 0.68 & 1.32 & 1.39 \\
\hline pha01 & target & 0.22876 & -0.18548 & 0.16308 & 0.13299 & 1.69 & 0.65 & 1.46 & 1.36 \\
\hline pha02 & measured & 0.10400 & -0.22546 & 0.06252 & 0.08270 & 1.27 & 0.60 & 1.15 & 1.21 \\
\hline pha02 & measured bc & 0.10532 & -0.22870 & 0.07145 & 0.09095 & 1.27 & 0.59 & 1.18 & 1.23 \\
\hline pha02 & target & 0.08996 & -0.22741 & 0.07491 & 0.09208 & 1.23 & 0.59 & 1.19 & 1.24 \\
\hline pha03 & measured & 0.24524 & -0.15256 & 0.19801 & 0.20929 & 1.76 & 0.70 & 1.58 & 1.62 \\
\hline pha03 & measured bc & 0.24650 & -0.15584 & 0.20697 & 0.21755 & 1.76 & 0.70 & 1.61 & 1.65 \\
\hline pha03 & target & 0.23317 & -0.15546 & 0.19886 & 0.21765 & 1.71 & 0.70 & 1.58 & 1.65 \\
\hline pha04 & measured & 0.18716 & -0.13764 & 0.15247 & 0.17857 & 1.54 & 0.73 & 1.42 & 1.51 \\
\hline pha04 & measured bc & 0.18843 & -0.14060 & 0.16140 & 0.18683 & 1.54 & 0.72 & 1.45 & 1.54 \\
\hline pha04 & . target & 0.24029 & -0.11862 & 0.17676 & 0.19994 & 1.74 & 0.76 & 1.50 & 1.58 \\
\hline pha05 & measured & 0.11243 & -0.20595 & 0.04395 & 0.06108 & 1.30 & 0.62 & 1.11 & 1.15 \\
\hline pha05 & measured bc & 0.11357 & -0.20981 & 0.05294 & 0.06938 & 1.30 & 0.62 & 1.13 & 1.17 \\
\hline pha05 & target & 0.07434 & -0.22399 & 0.04190 & 0.07092 & 1.19 & 0.60 & 1.10 & 1.18 \\
\hline pha06 & measured & 0.19514 & -0.17575 & 0.15701 & 0.17256 & 1.57 & 0.67 & 1.44 & $1.49^{\circ}$ \\
\hline pha06 & measured bc & 0.19623 & -0.17897 & 0.16598 & 0.18082 & 1.57 & 0.66 & 1.47 & 1.52 \\
\hline pha06 & target & 0.17947 & -0.17343 & 0.15859 & 0.17909 & 1.51 & 0.67 & 1.44 & 1.51 \\
\hline pha07 & measured & -0.02381 & -0.26919 & -0.06227 & 0.00931 & 0.95 & 0.54 & 0.87 & 1.02 \\
\hline pha07 & measured bc & -0.00742 & -0.27576 & -0.05351 & -0.01391 & 0.98 & 0.53 & 0.88 & 0.97 \\
\hline pha07 & . target & -0.02225 & -0.27343 & -0.06468 & -0.01793 & 0.95 & 0.53 & 0.86 & 0.96 \\
\hline pha08 & measured & 0.00957 & -0.25541 & 0.00584 & 0.05032 & 1.02 & 0.56 & 1.01 & 1.12 \\
\hline pha08 & measured bc & 0.02632 & -0.26206 & 0.01467 & 0.02706 & 1.06 & 0.55 & 1.03 & 1.06 \\
\hline pha08 & target & 0.02358 & -0.24200 & 0.01248 & 0.02697 & 1.06 & 0.57 & 1.03 & 1.06 \\
\hline pha09 & measured & 0.08636 & -0.23318 & 0.07789 & 0.11318 & 1.22 & 0.58 & 1.20 & 1.30 \\
\hline pha09 & measured bc & 0.10245 & -0.24088 & 0.08672 & 0.08993 & 1.27 & 0.57 & 1.22 & 1.23 \\
\hline pha09 & target & 0.09068 & -0.21591 & 0.07595 & 0.10653 & 1.23 & 0.61 & 1.19 & 1.28 \\
\hline pha10 & measured & -0.04560 & -0.27228 & -0.05734 & 0.00946 & 0.90 & 0.53 & 0.88 & 1.02 \\
\hline pha10 & measured bc & -0.02942 & -0.27930 & -0.04879 & -0.01400 & 0.93 & 0.53 & 0.89 & 0.97 \\
\hline pha10 & target & -0.02188 & -0.25917 & -0.04947 & -0.00349 & 0.95 & 0.55 & 0.89 & 0.99 \\
\hline pha11 & measured & 0.03705 & -0.26094 & 0.03230 & 0.08296 & 1.09 & 0.55 & 1.08 & 1.21 \\
\hline pha11 & measured bc & 0.05290 & -0.26830 & 0.04094 & 0.05974 & 1.13 & 0.54 & 1.10 & 1.15 \\
\hline pha11 & target & 0.06596 & -0.22838 & 0.03710 & 0.06953 & 1.16 & 0.59 & 1.09 & 1.17 \\
\hline phallc & measured & 0.00658 & -0.27729 & -0.00643 & 0.00240 & 1.02 & 0.53 & 0.99 & 1.01 \\
\hline pha11c & measured bc & 0.00612 & -0.28101 & 0.00504 & 0.01831 & 1.01 & 0.52 & 1.01 & 1.04 \\
\hline pha11c & target & 0.00815 & -0.26651 & -0.00793 & 0.02095 & 1.02 & 0.54 & 0.98 & 1.05 \\
\hline pha12 & measured & 0.17482 & -0.20543 & 0.14331 & 0.17769 & 1.50 & 0.62 & 1.39 & 1.51 \\
\hline pha12 & measured bc & 0.19069 & -0.21280 & 0.15203 & 0.15448 & 1.55 & 0.61 & 1.42 & 1.43 \\
\hline pha12 & target & 0.19798 & -0.17386 & 0.14617 & 0.16850 & 1.58 & 0.67 & 1.40 & 1.47 \\
\hline pha12c & measured & 0.17737 & -0.19919 & 0.15490 & 0.15261 & 1.50 & 0.63 & 1.43 & 1.42 \\
\hline pha12c & measured bc & 0.17672 & -0.20293 & 0.16637 & 0.16851 & 1.50 & 0.63 & 1.47 & 1.47 \\
\hline pha12c & target & 0.18039 & -0.18344 & 0.15610 & 0.18061 & 1.51 & 0.66 & 1.43 & 1.52 \\
\hline pha13 & measured & 0.00224 & -0.29231 & -0.00987 & -0.01053 & 1.01 & 0.51 & 0.98 & 0.98 \\
\hline pha13 & measured bc & 0.00188 & -0.29945 & -0.02678 & -0.00603 & 1.00 & 0.50 & 0.94 & 0.99 \\
\hline pha13 & target & 0.01087 & -0.30154 & -0.01099 & -0.01280 & 1.03 & 0.50 & 0.98 & 0.97 \\
\hline pha14c & measured & 0.06317 & -0.25322 & 0.03246 & 0.03802 & 1.16 & 0.56 & 1.08 & 1.09 \\
\hline pha14c & target & 0.03885 & -0.26697 & 0.02967 & 0.03252 & 1.09 & 0.54 & 1.07 & 1.08 \\
\hline pha15c & measured & 0.24023 & -0.19416 & 0.17513 & 0.18018 & 1.74 & 0.64 & 1.50 & 1.51 \\
\hline pha15c & target & 0.21601 & -0.20994 & 0.17687 & 0.17711 & 1.64 & 0.62 & 1.50 & 1.50 \\
\hline
\end{tabular}


WSRC-TR-99-00332

Revision 0

Table A.4: Normalized PCTs for the CST Glasses

\begin{tabular}{|cccccccccc|}
\hline Glass ID & Composition & {$[\mathrm{B}(\mathrm{g} / \mathrm{L})]$} & {$[\mathrm{Si}(\mathrm{g} / \mathrm{L})]$} & {$[\mathrm{Na}(\mathrm{g} / \mathrm{L})]$} & {$[\mathrm{Li}(\mathrm{g} / \mathrm{L})]$} & $\mathrm{B}(\mathrm{g} / \mathrm{L})$ & $\mathrm{Si}(\mathrm{g} / \mathrm{L})$ & $\mathrm{Na}(\mathrm{g} / \mathrm{L})$ & $\mathrm{Li}(\mathrm{g} / \mathrm{L})$ \\
pha16 & measured & 0.02870 & -0.28244 & 0.00482 & 0.01993 & 1.07 & 0.52 & 1.01 & 1.05 \\
pha16 & measured bc & 0.02834 & -0.28916 & -0.01207 & 0.02446 & 1.07 & 0.51 & 0.97 & 1.06 \\
pha16 & target & 0.10080 & -0.27571 & 0.02577 & 0.02890 & 1.26 & 0.53 & 1.06 & 1.07 \\
pha17c & measured & 0.08084 & -0.26107 & 0.07914 & 0.06536 & 1.20 & 0.55 & 1.20 & 1.16 \\
pha17c & measured bc & 0.08047 & -0.26483 & 0.09060 & 0.08127 & 1.20 & 0.54 & 1.23 & 1.21 \\
pha17c & target & 0.06374 & -0.26312 & 0.05958 & 0.07393 & 1.16 & 0.55 & 1.15 & 1.19 \\
pha18c & measured & 0.24209 & -0.19310 & 0.19460 & 0.20194 & 1.75 & 0.64 & 1.57 & 1.59 \\
pha18c & measured bc & 0.24166 & -0.19699 & 0.20606 & 0.21784 & 1.74 & 0.64 & 1.61 & 1.65 \\
pha18c & target & 0.24667 & -0.18702 & 0.20982 & 0.22103 & 1.76 & 0.65 & 1.62 & 1.66 \\
pha20 & measured & -0.30200 & -0.52025 & -0.27890 & -0.24396 & 0.50 & 0.30 & 0.53 & 0.57 \\
pha20 & measured bc & -0.30245 & -0.52376 & -0.26743 & -0.22806 & 0.50 & 0.30 & 0.54 & 0.59 \\
pha20 & target & -0.30793 & -0.52678 & -0.29405 & -0.24342 & 0.49 & 0.30 & 0.51 & 0.57 \\
pha26 & measured & -0.33060 & -0.54519 & -0.31561 & -0.26829 & 0.47 & 0.28 & 0.48 & 0.54 \\
pha26 & measured bc & -0.33098 & -0.54660 & -0.30414 & -0.25238 & 0.47 & 0.28 & 0.50 & 0.56 \\
pha26 & target & -0.33691 & -0.53916 & -0.31714 & -0.25972 & 0.46 & 0.29 & 0.48 & 0.55 \\
pha32 & measured & -0.33341 & -0.53492 & -0.30177 & -0.25942 & 0.46 & 0.29 & 0.50 & 0.55 \\
pha32 & measured bc & -0.33383 & -0.53848 & -0.29031 & -0.24352 & 0.46 & 0.29 & 0.51 & 0.57 \\
pha32 & target & -0.34298 & -0.53649 & -0.30997 & -0.25411 & 0.45 & 0.29 & 0.49 \\
\hline
\end{tabular}




\section{Exhibit A.1: Comparisons of Measured Versus Target Compositions}

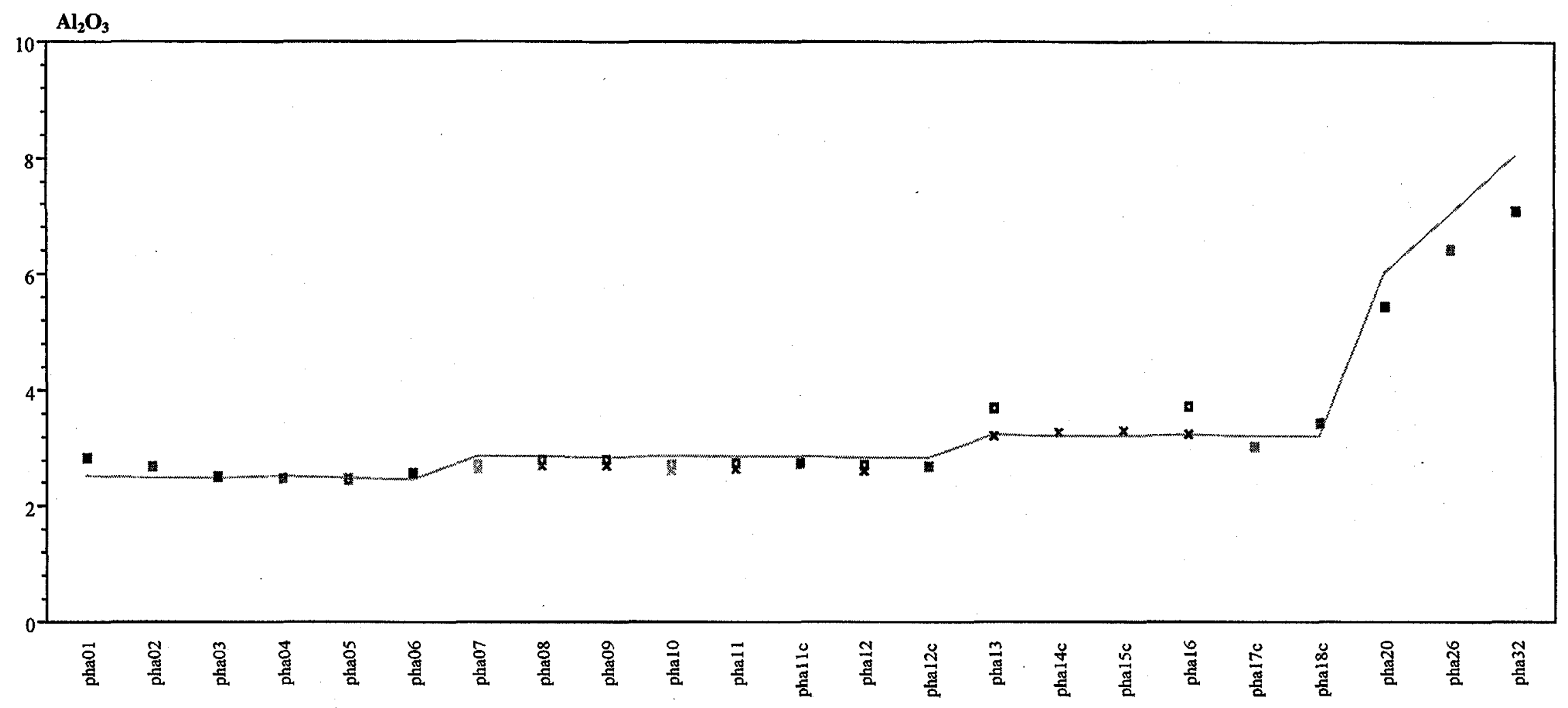



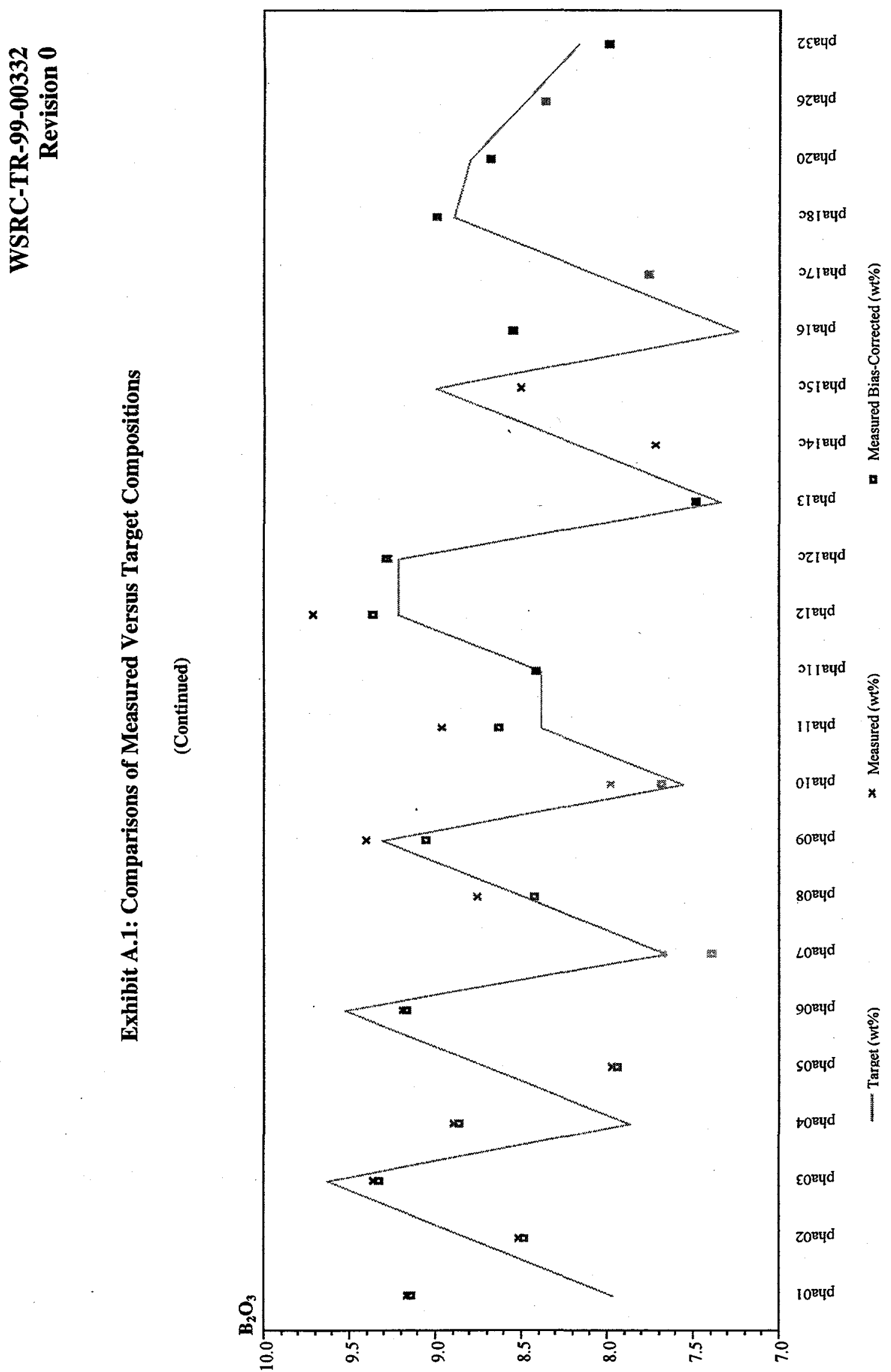


\section{Exhibit A.1: Comparisons of Measured Versus Target Compositions}

(Continued)

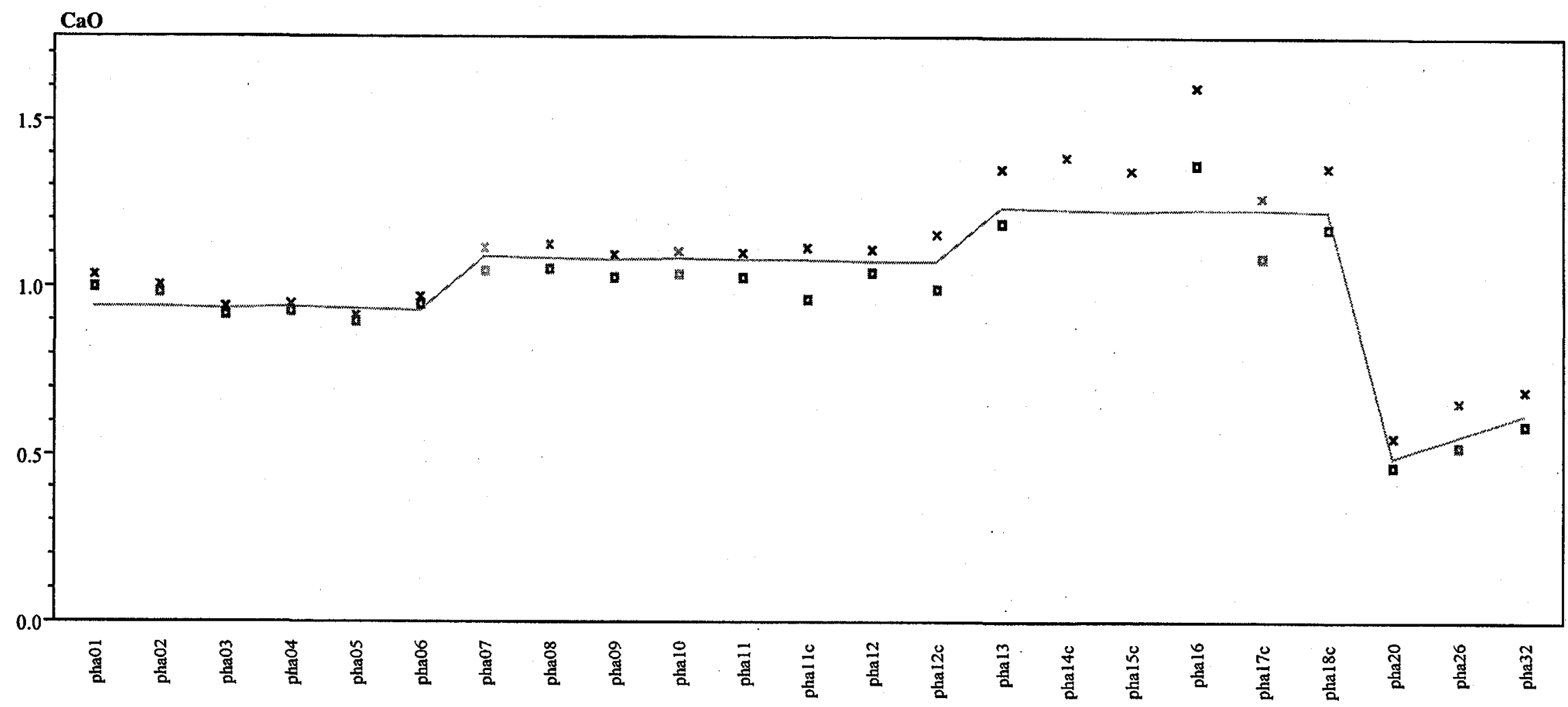



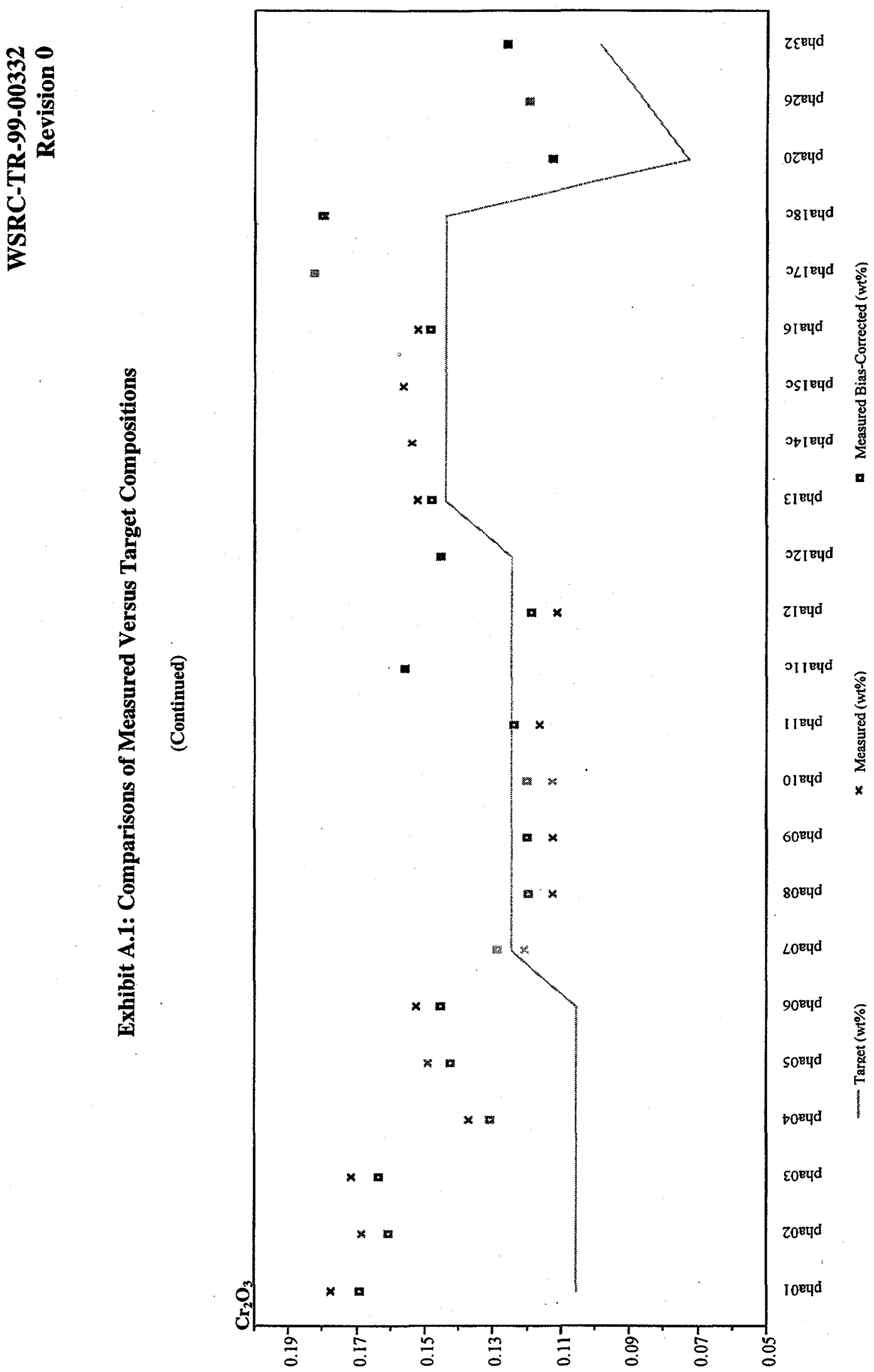

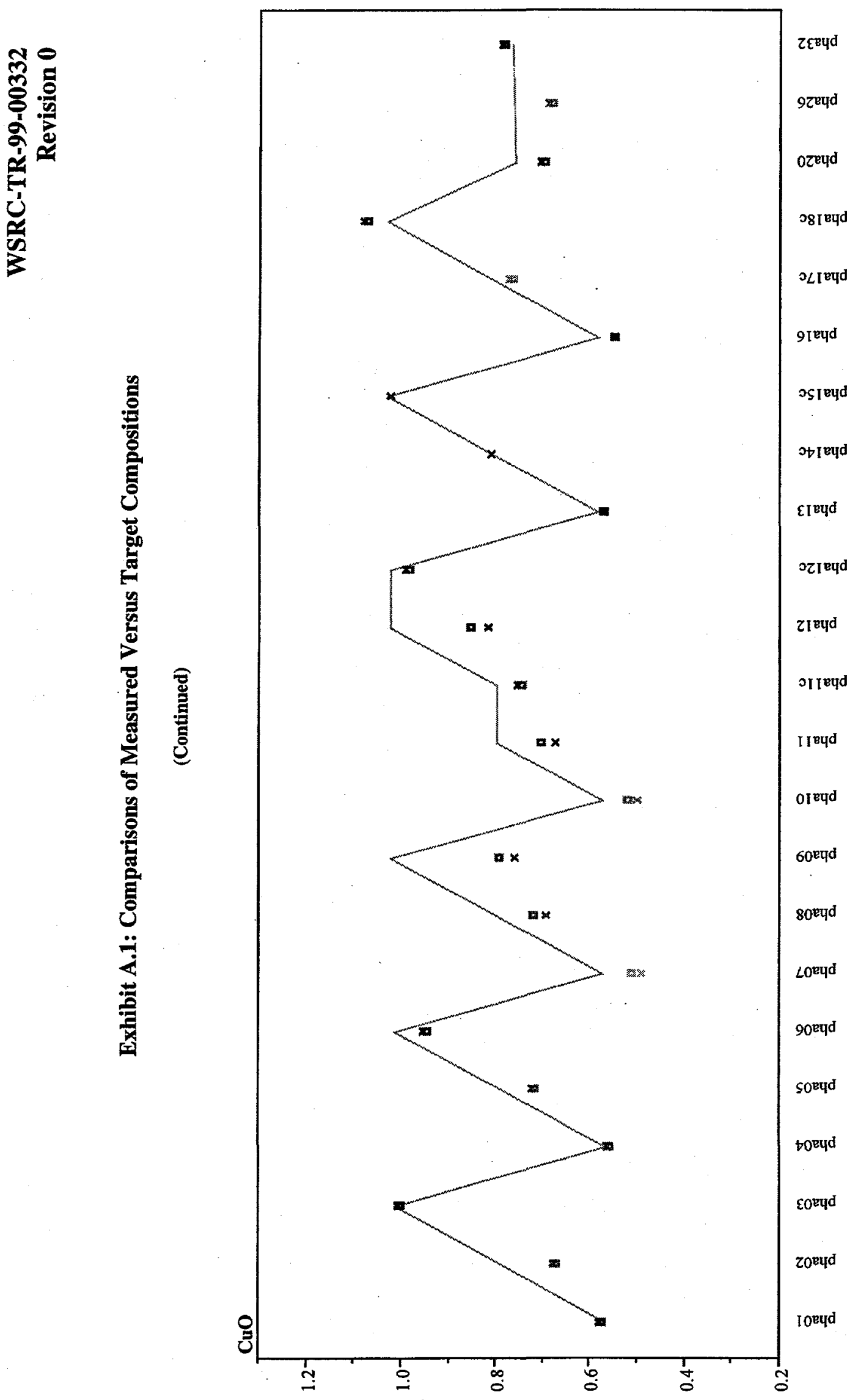

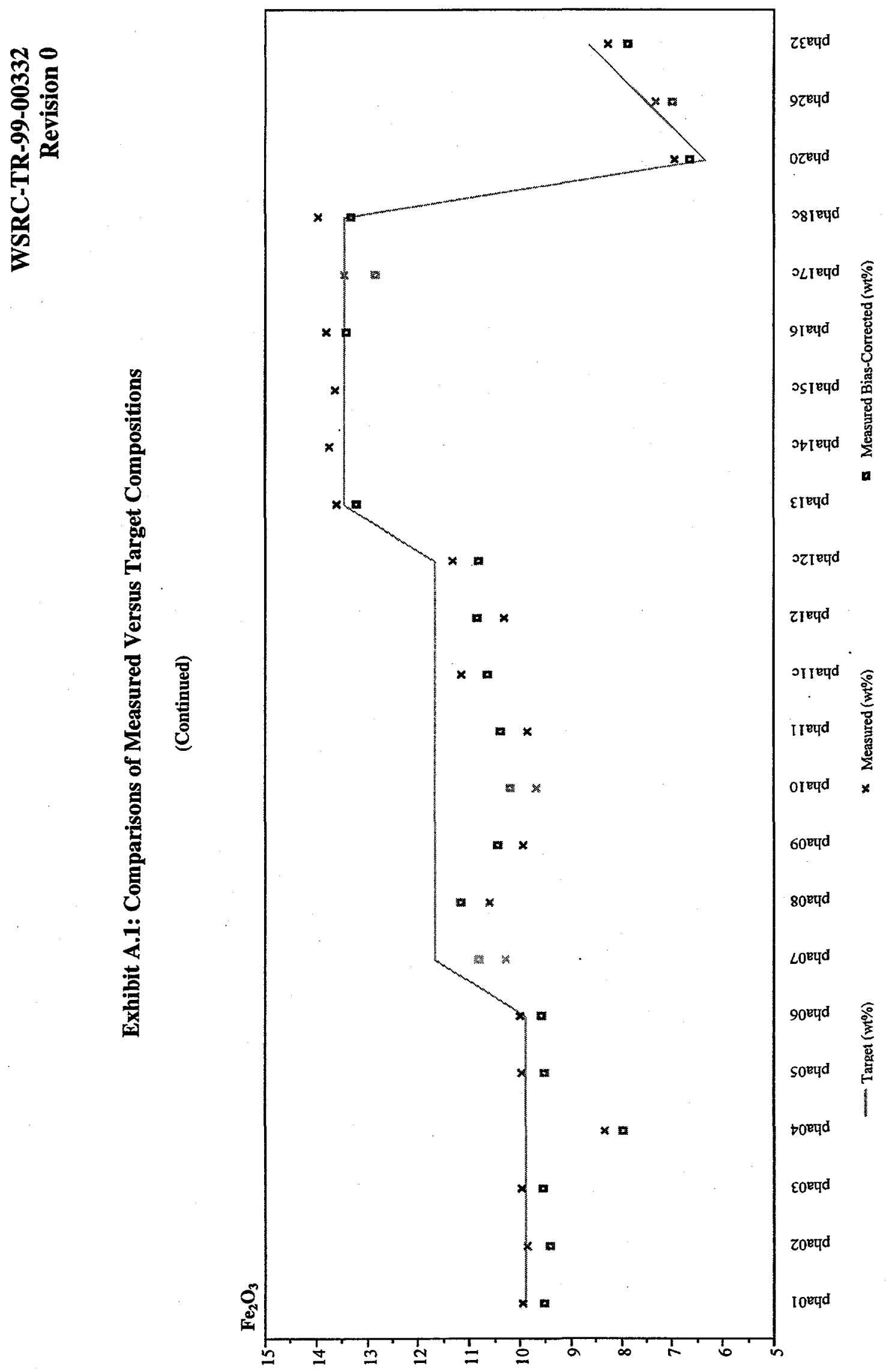


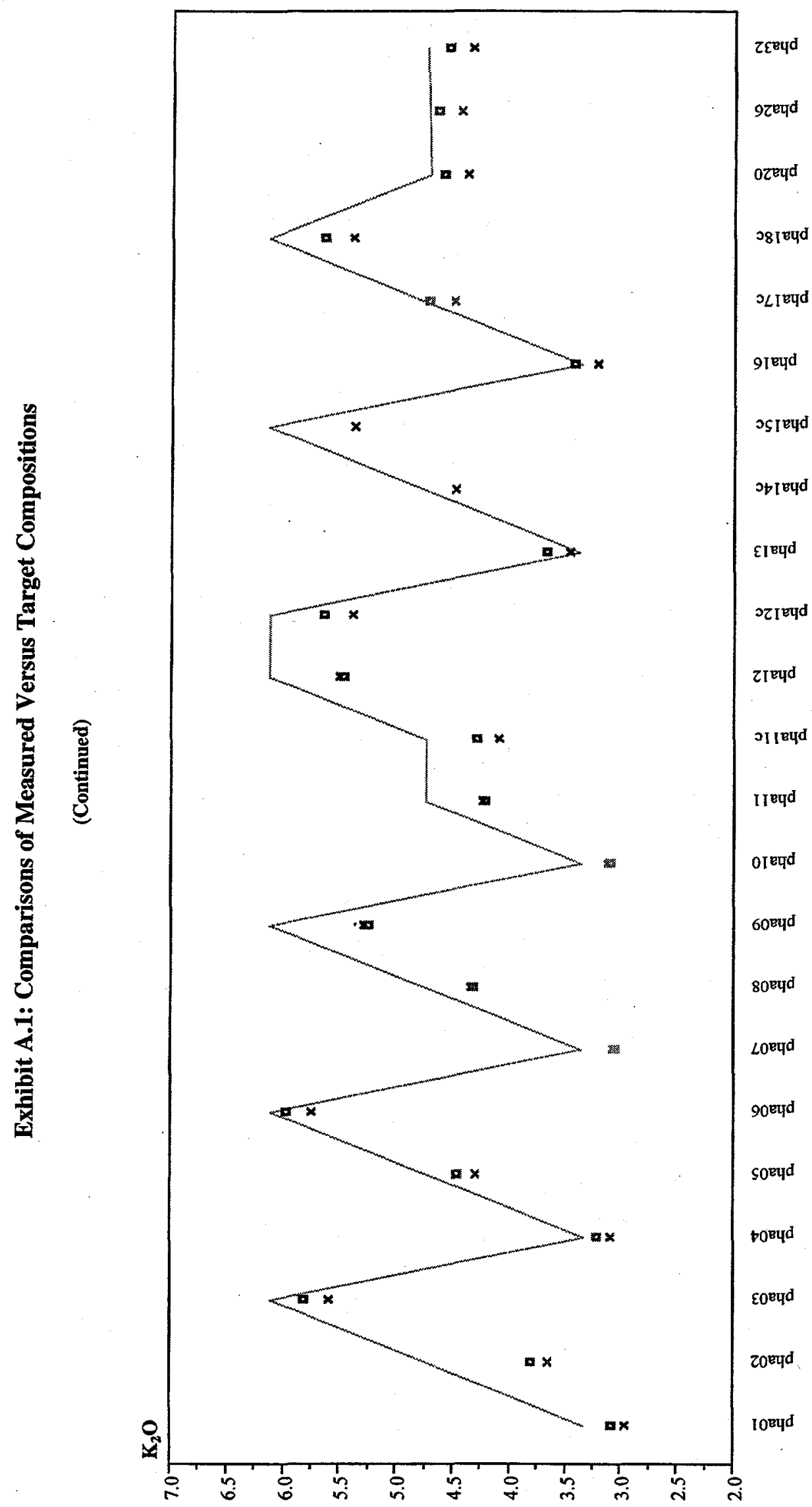



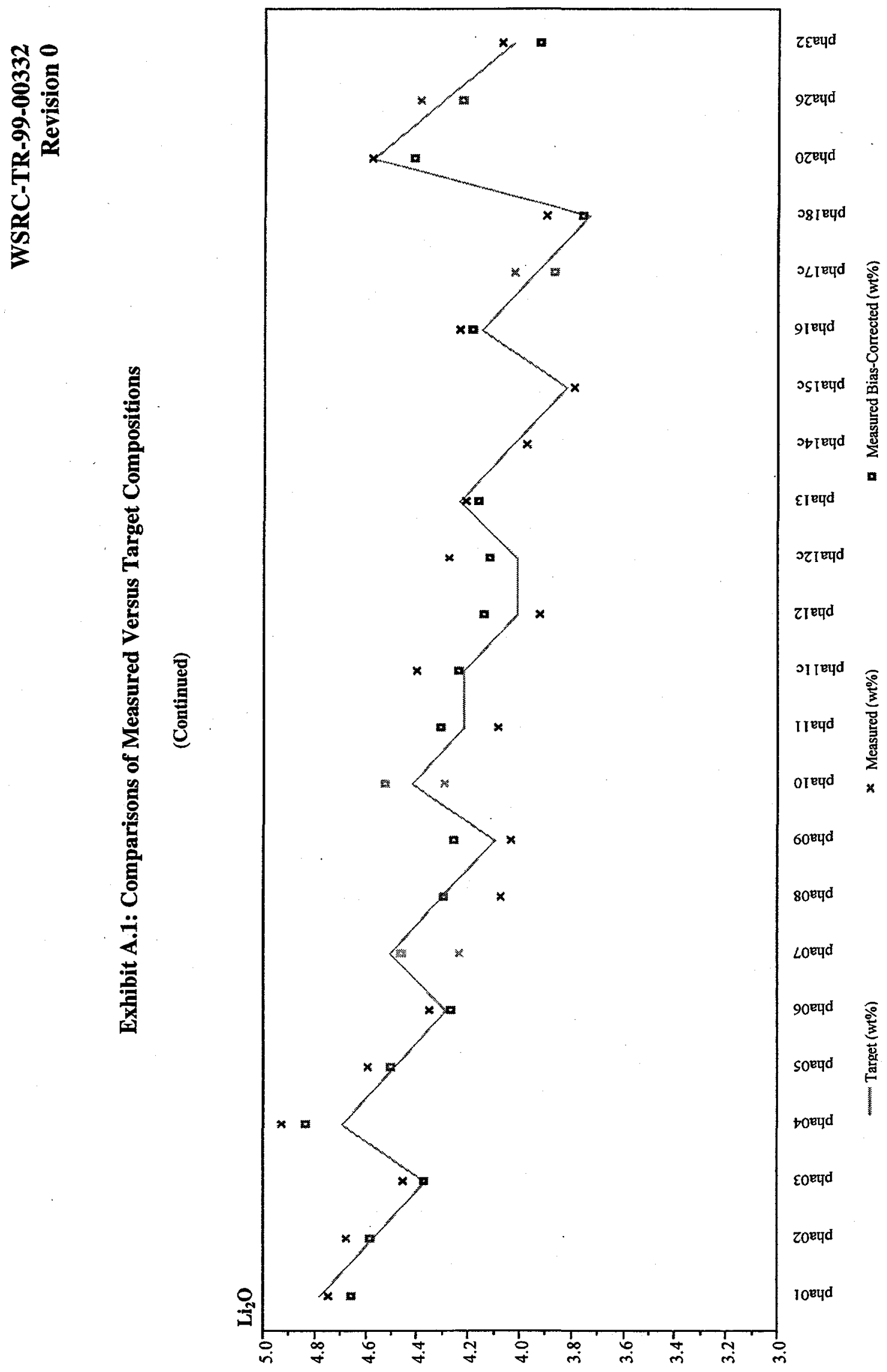

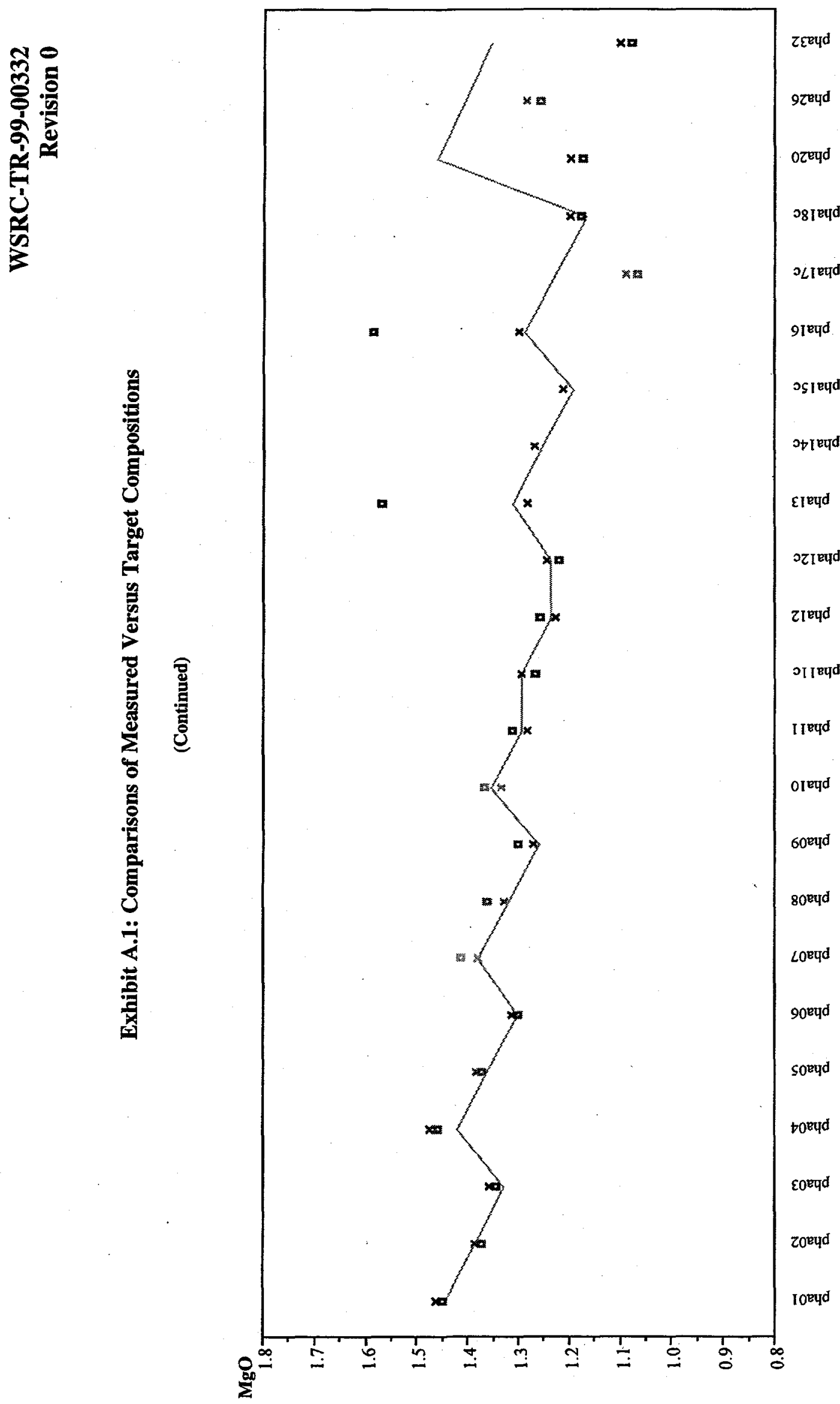

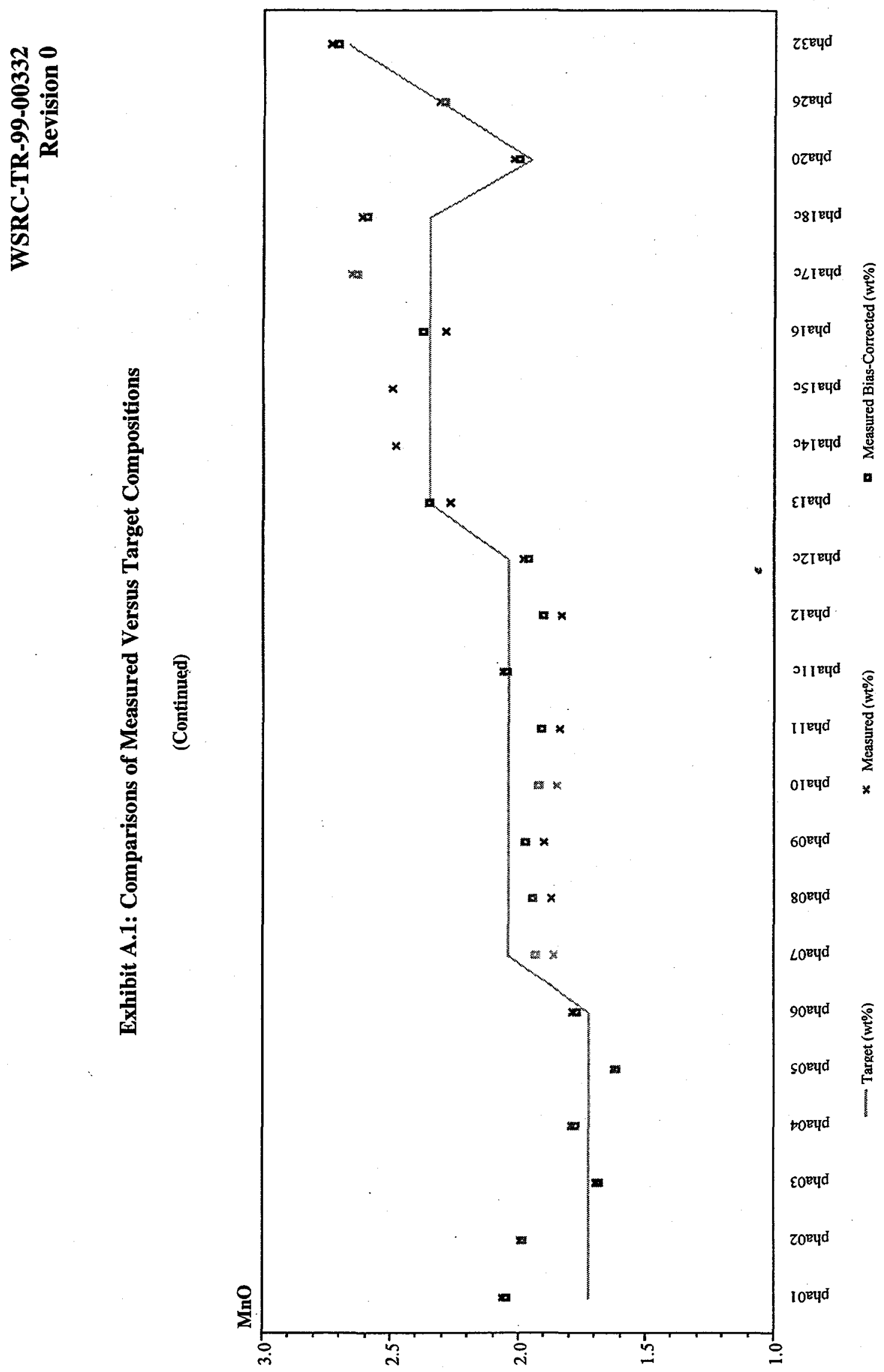


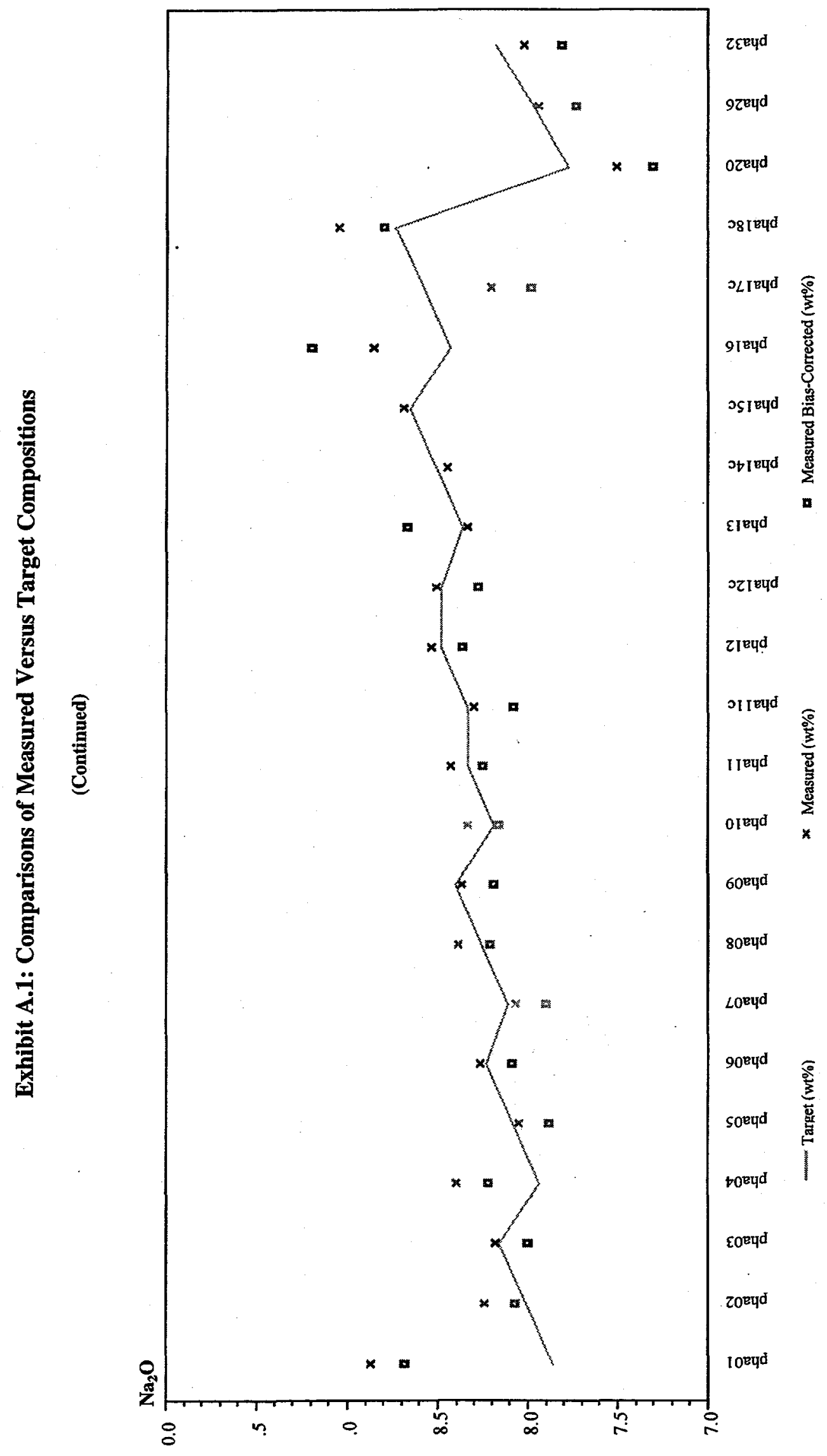




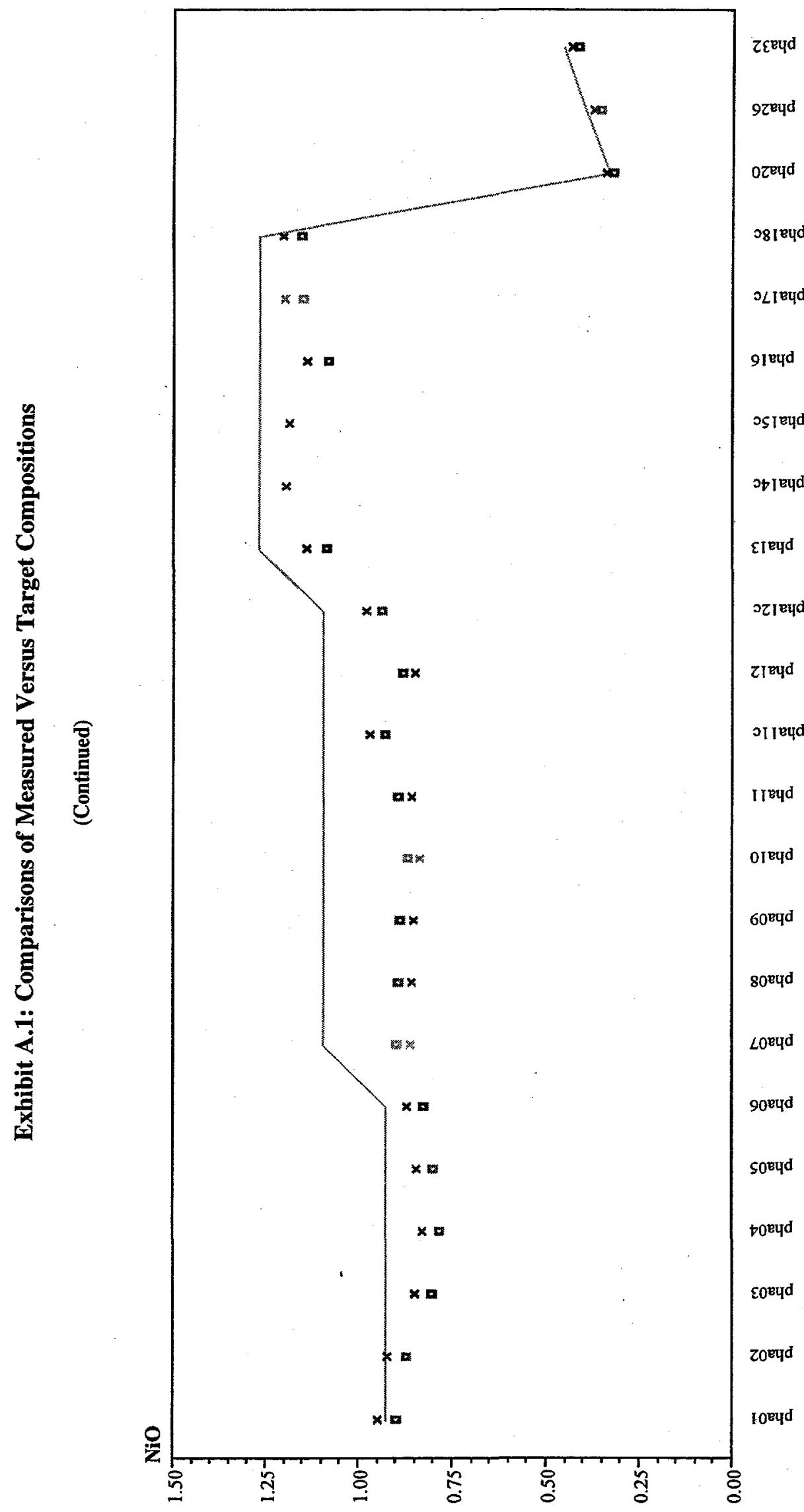




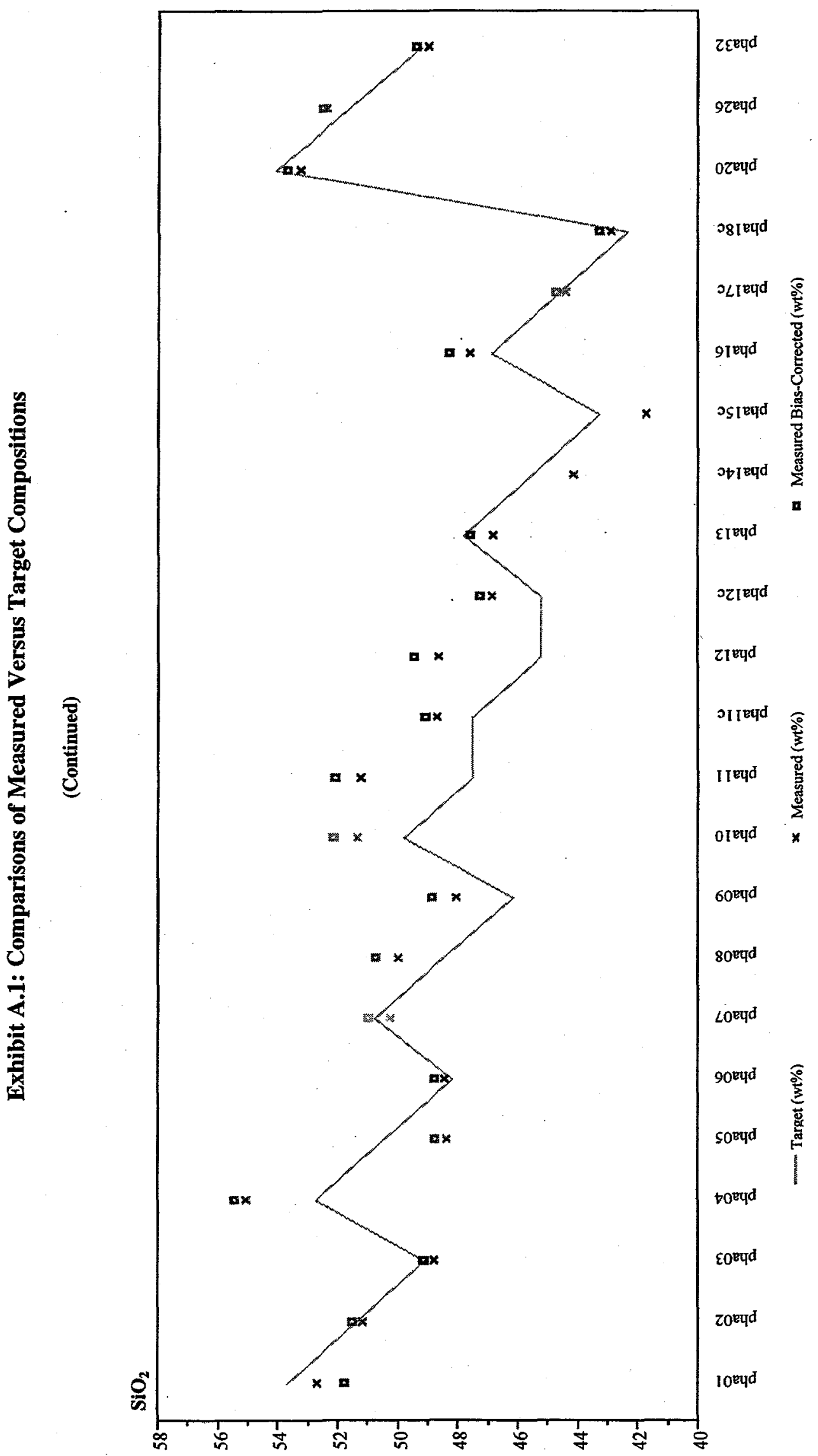



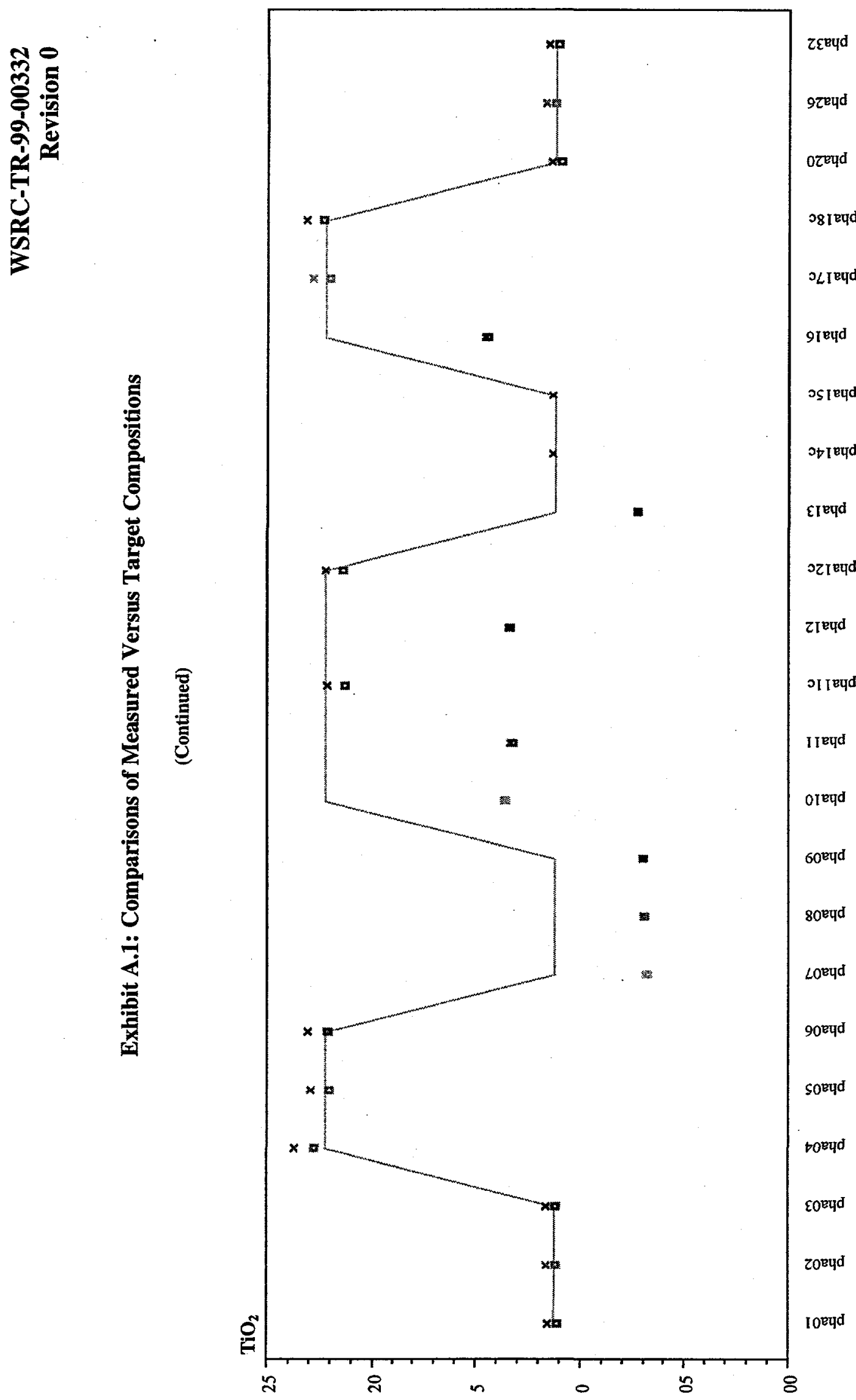


\section{WSRC-TR-99-00332}

Revision 0

\section{Exhibit A.1: Comparisons of Measured Versus Target Compositions}

(Continued)

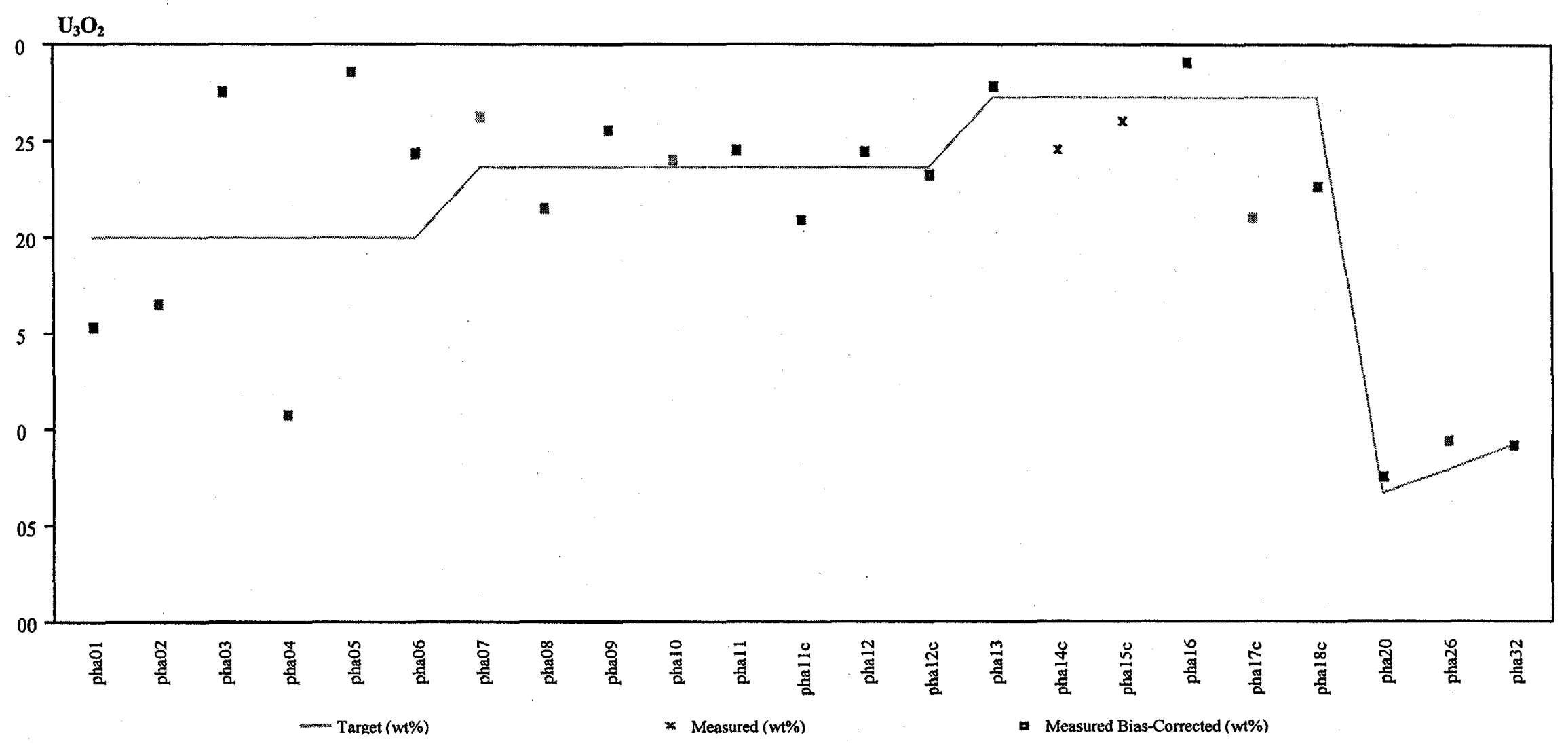


Revision 0

Exhibit A.1: Comparisons of Measured Versus Target Compositions

(Continued)

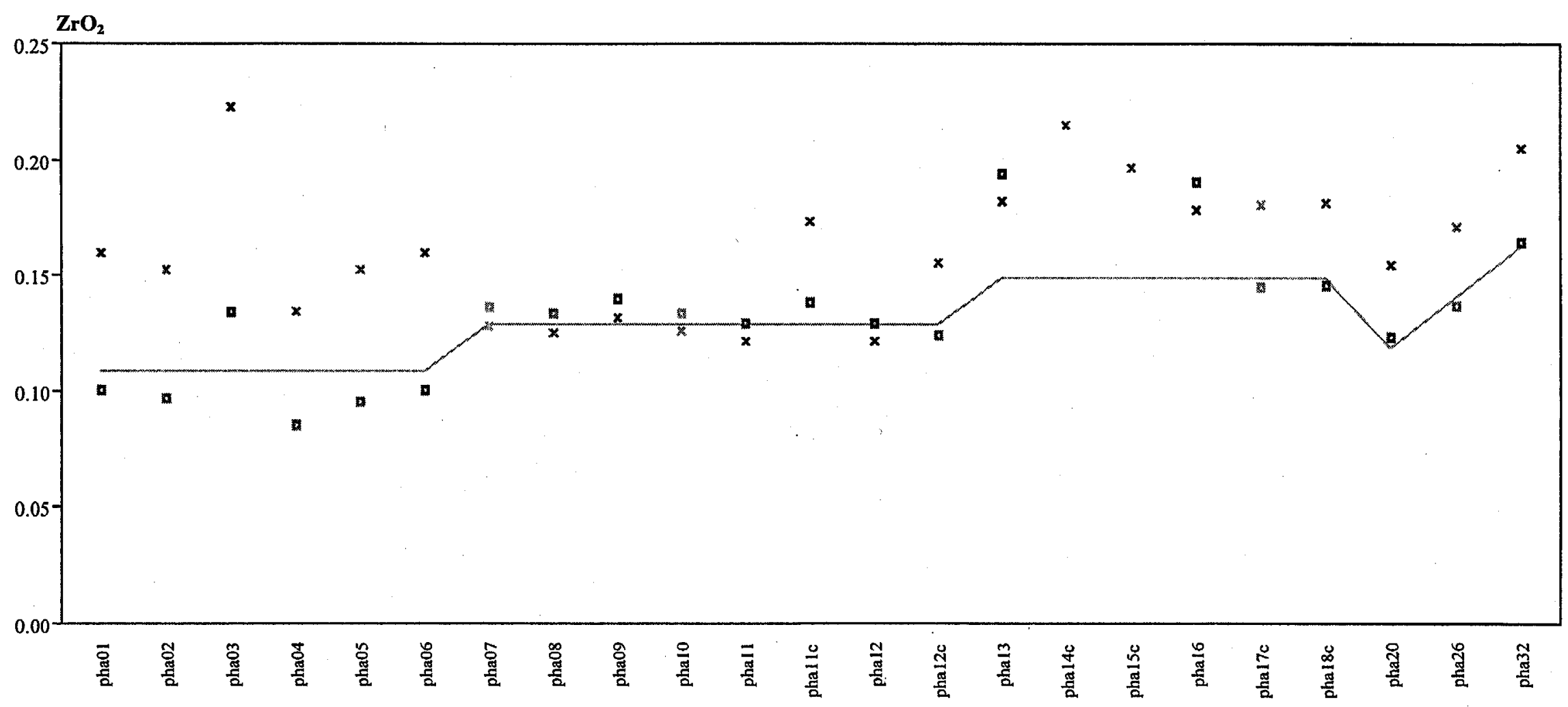




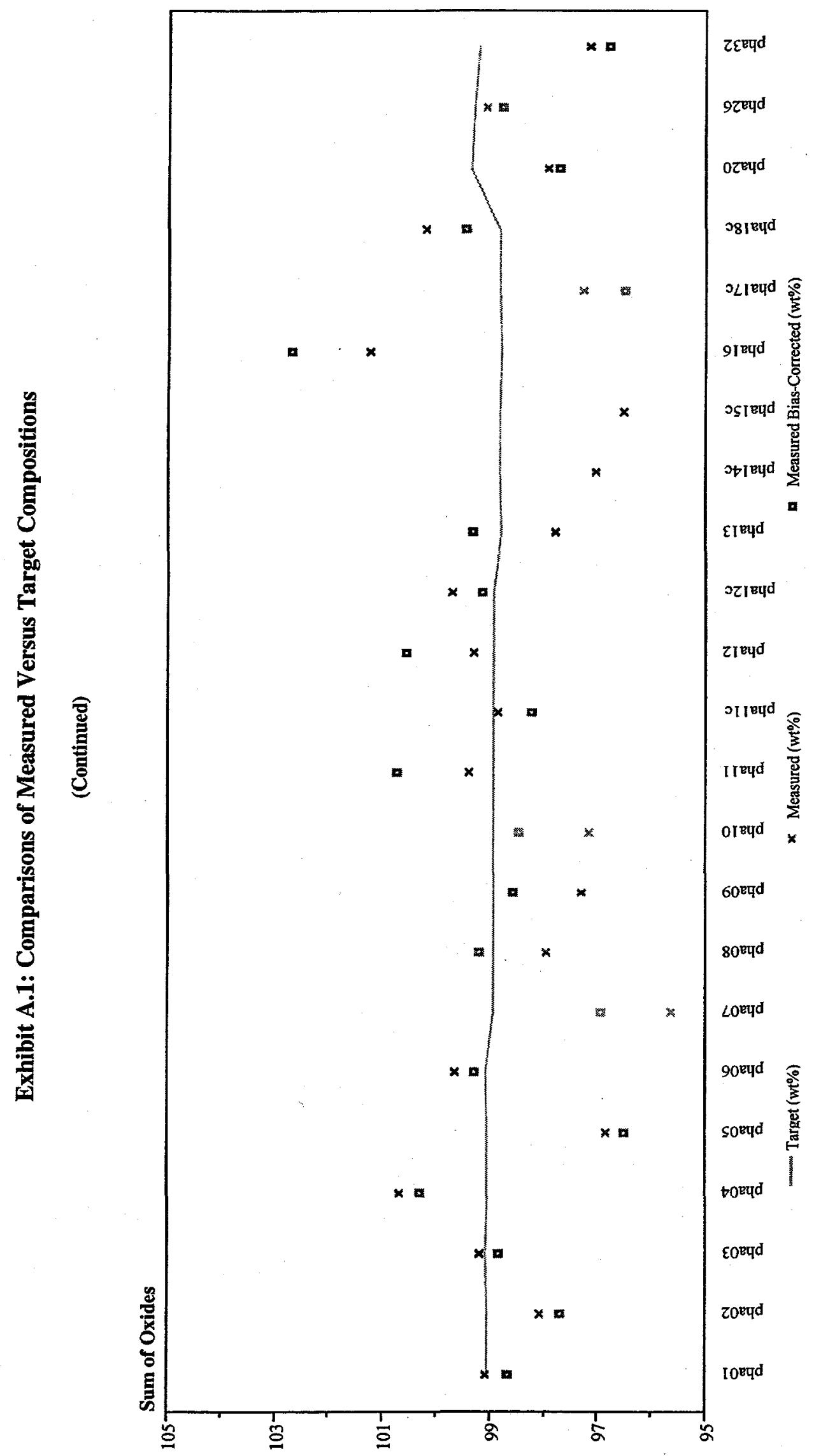


Exhibit A.2: Durability Predictions Versus Measurements

$\log N L(B)(g / L)$ By del Gp

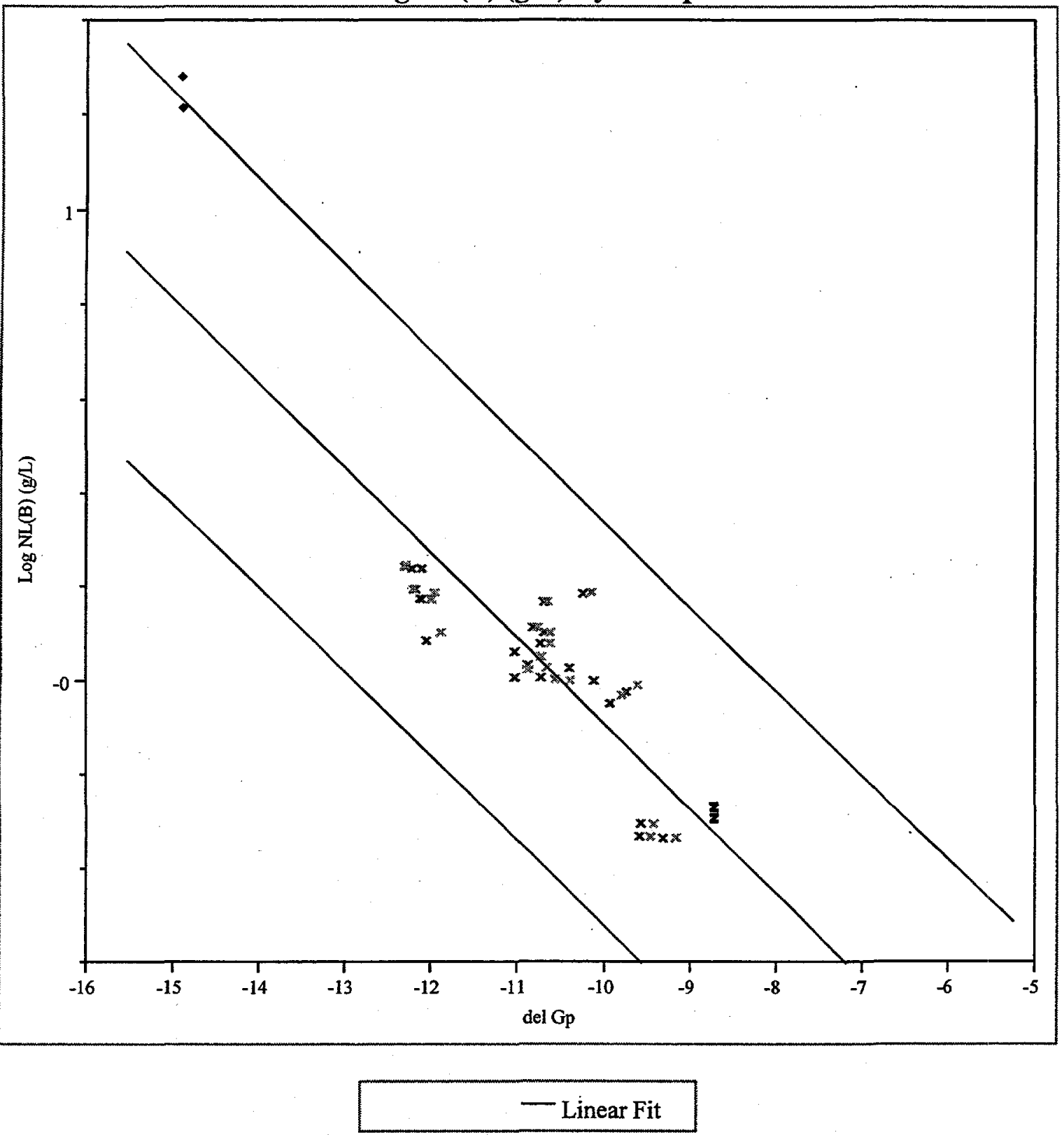

PCTs normalized and del $\mathrm{G}_{\mathrm{p}}$ determined from measured and meaured bias-corrected compositions. 
Exhibit A.2: Durability Predictions Versus Measurements (continued)

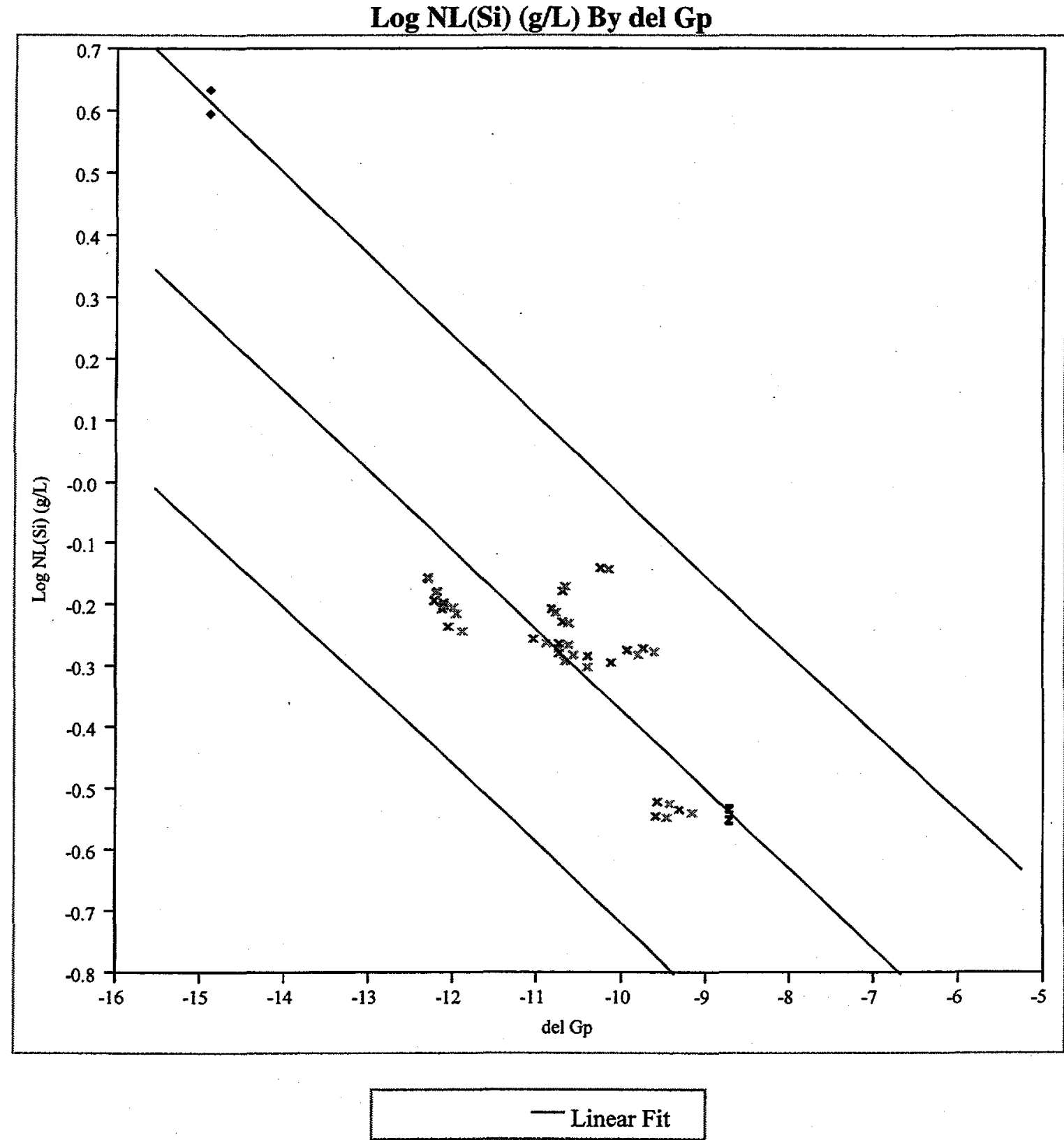

PCTs normalized and del $\mathrm{G}_{\mathrm{p}}$ determined from measured and meaured bias-corrected compositions. 
Exhibit A.2: Durability Predictions Versus Measurements (continued)

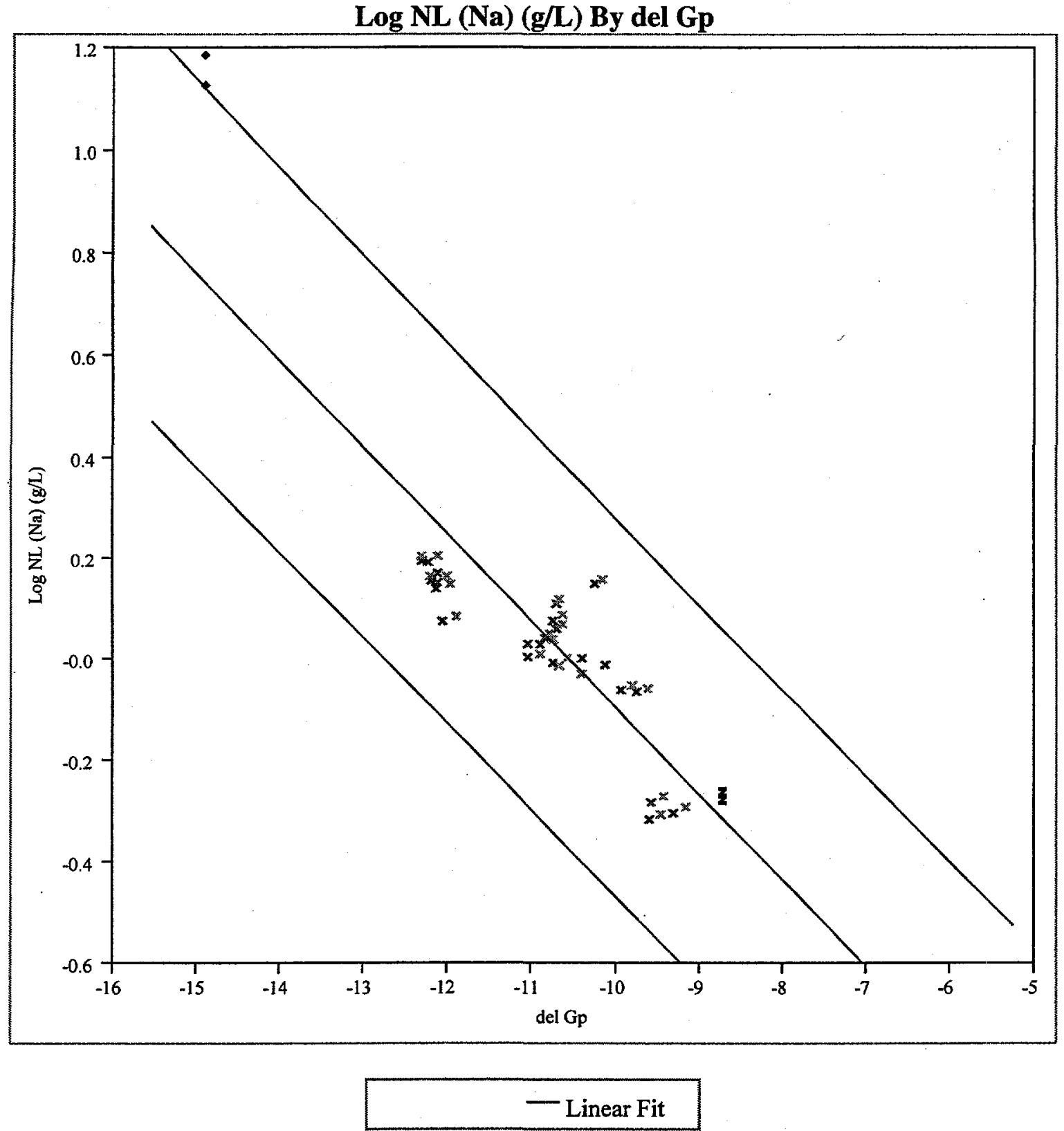

PCTs normalized and del $G_{p}$ determined from measured and meaured bias-corrected compositions. 
Exhibit A.2: Durability Predictions Versus Measurements (continued)

$\log [N L(L i) g / L]$ By del Gp

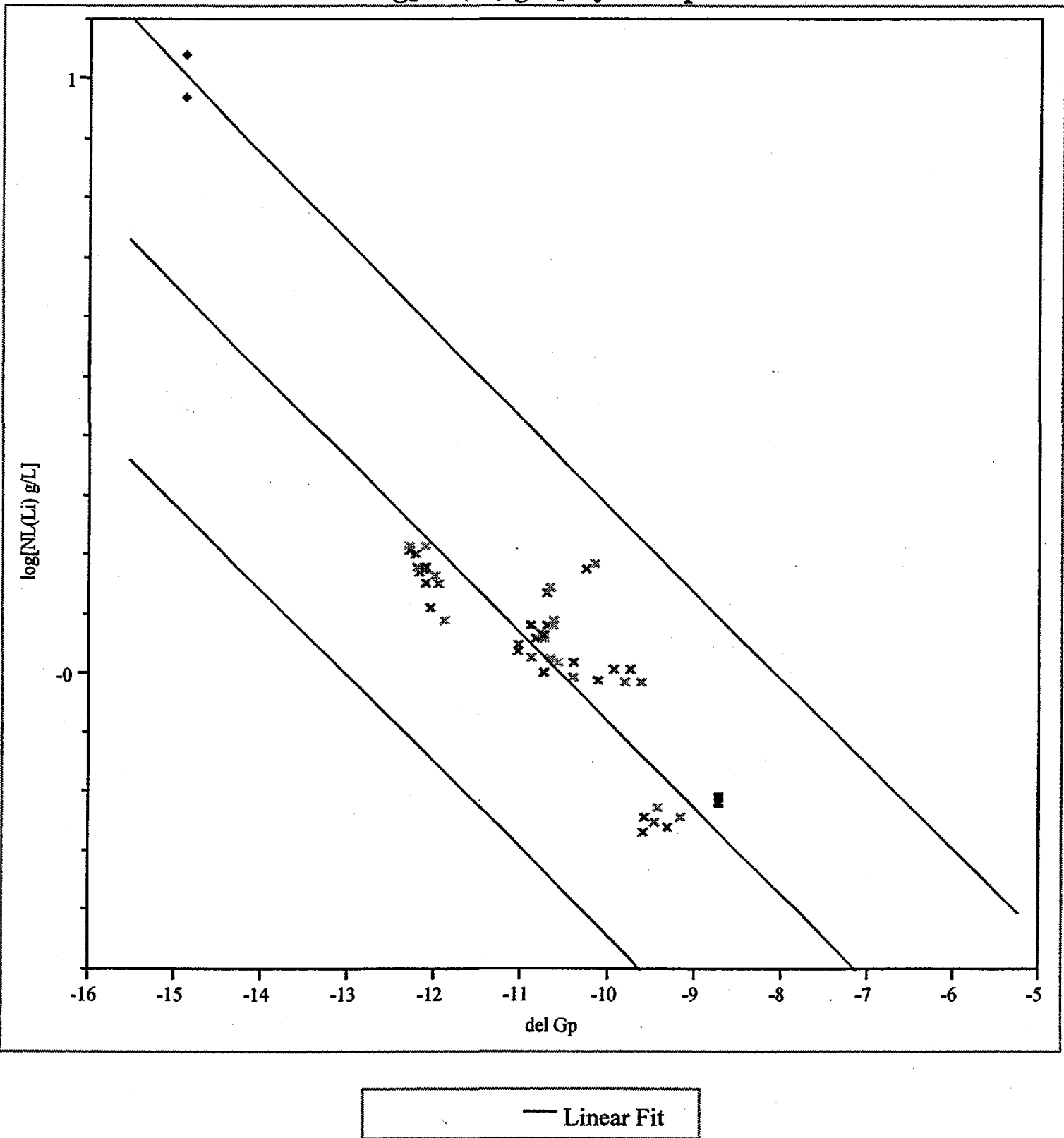

PCTs normalized and del $G_{p}$ determined from measured and meaured bias-corrected compositions. 
Exhibit A.2: Durability Predictions Versus Measurements

(continued)

\section{$\log$ NL(B) (g/L) By del Gp}

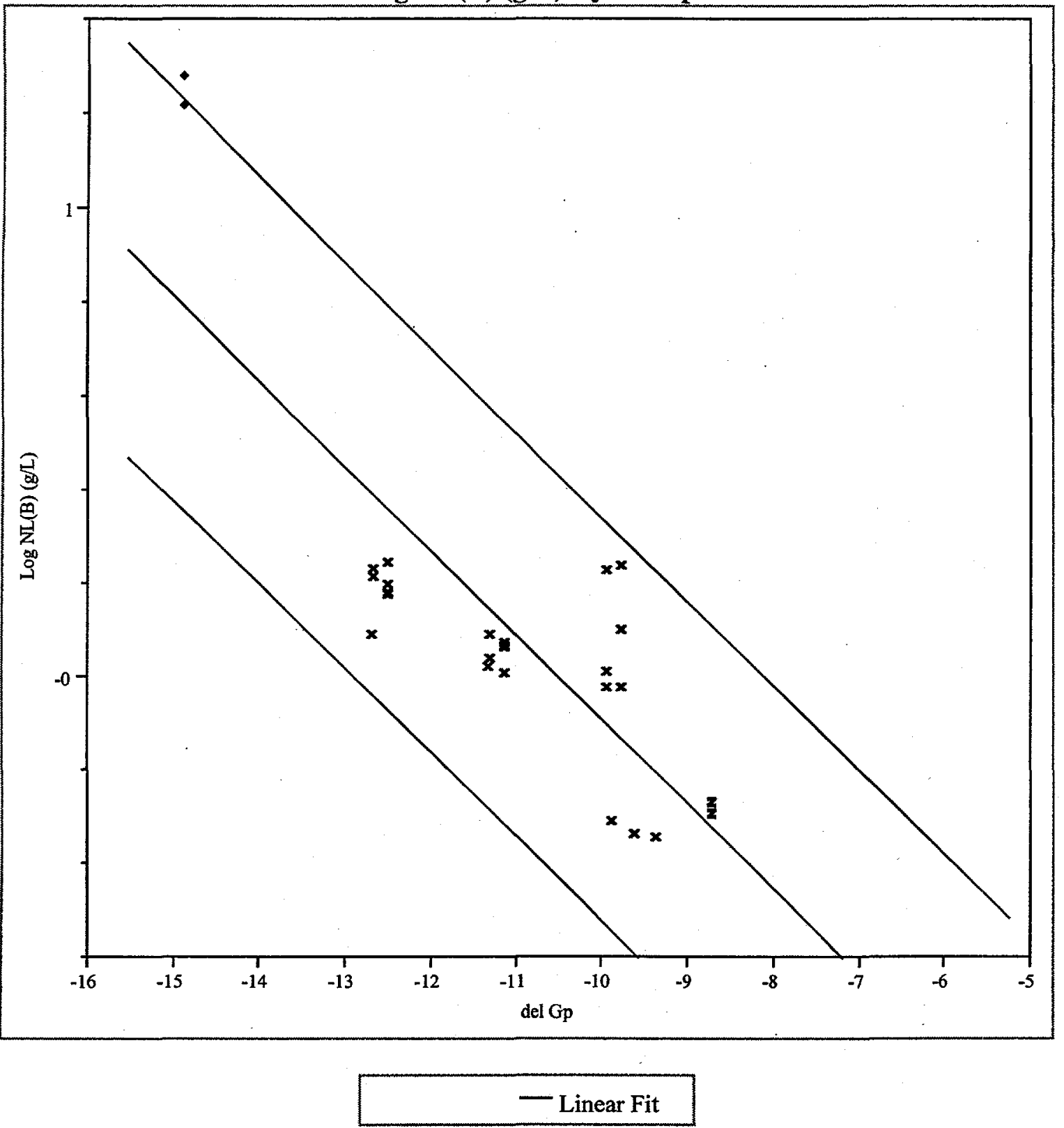

PCTs normalized and del $\mathrm{G}_{\mathrm{p}}$ determined from target compositions. 
Exhibit A.2: Durability Predictions Versus Measurements (continued)

$\log N L(S i)(g / L)$ By del Gp

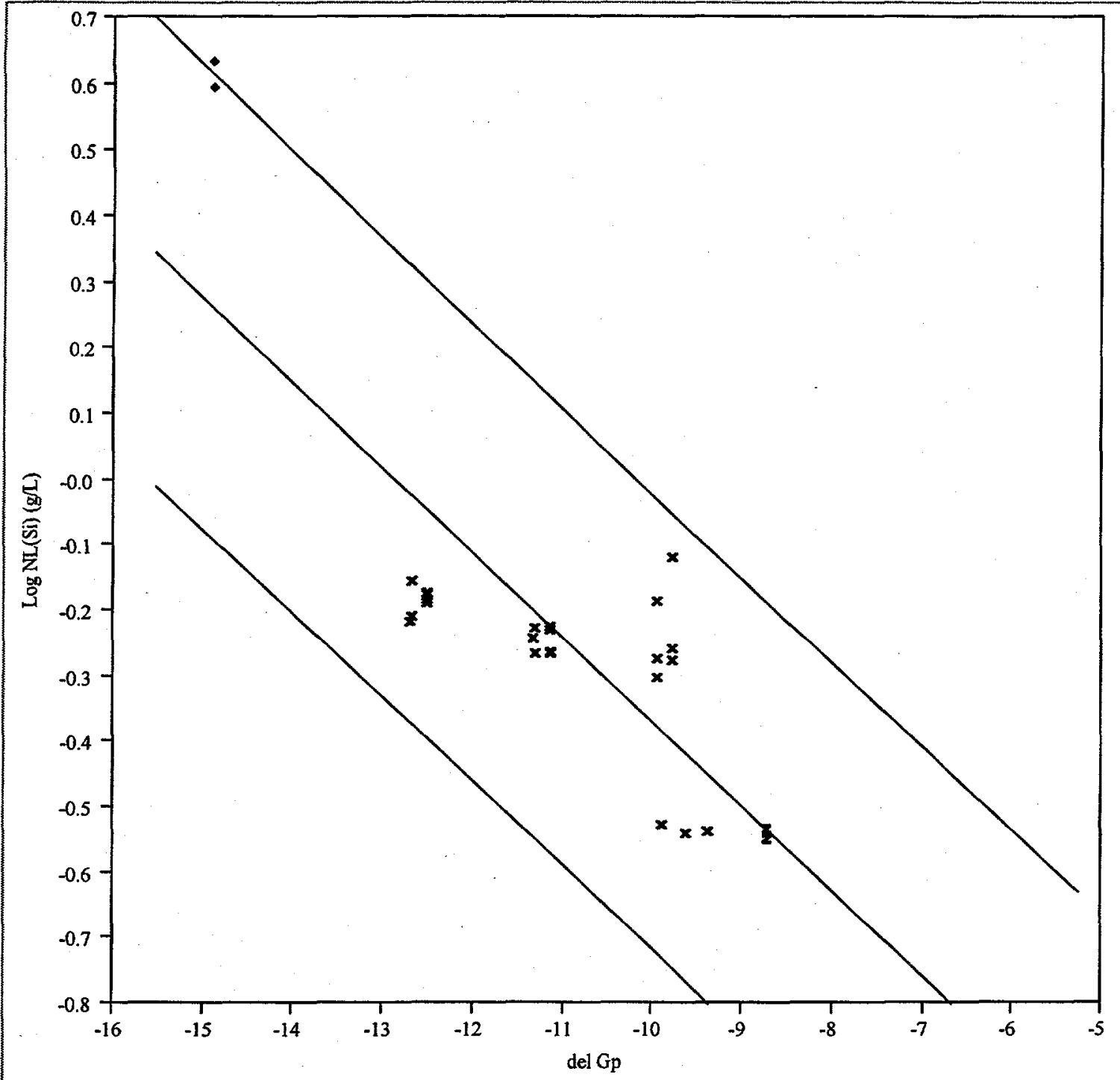

- Linear Fit

PCTs normalized and del $\mathrm{G}_{\mathrm{p}}$ determined from target compositions. 
Exhibit A.2: Durability Predictions Versus Measurements

(continued)

$\log N L(N a)$ (g/L) By del Gp

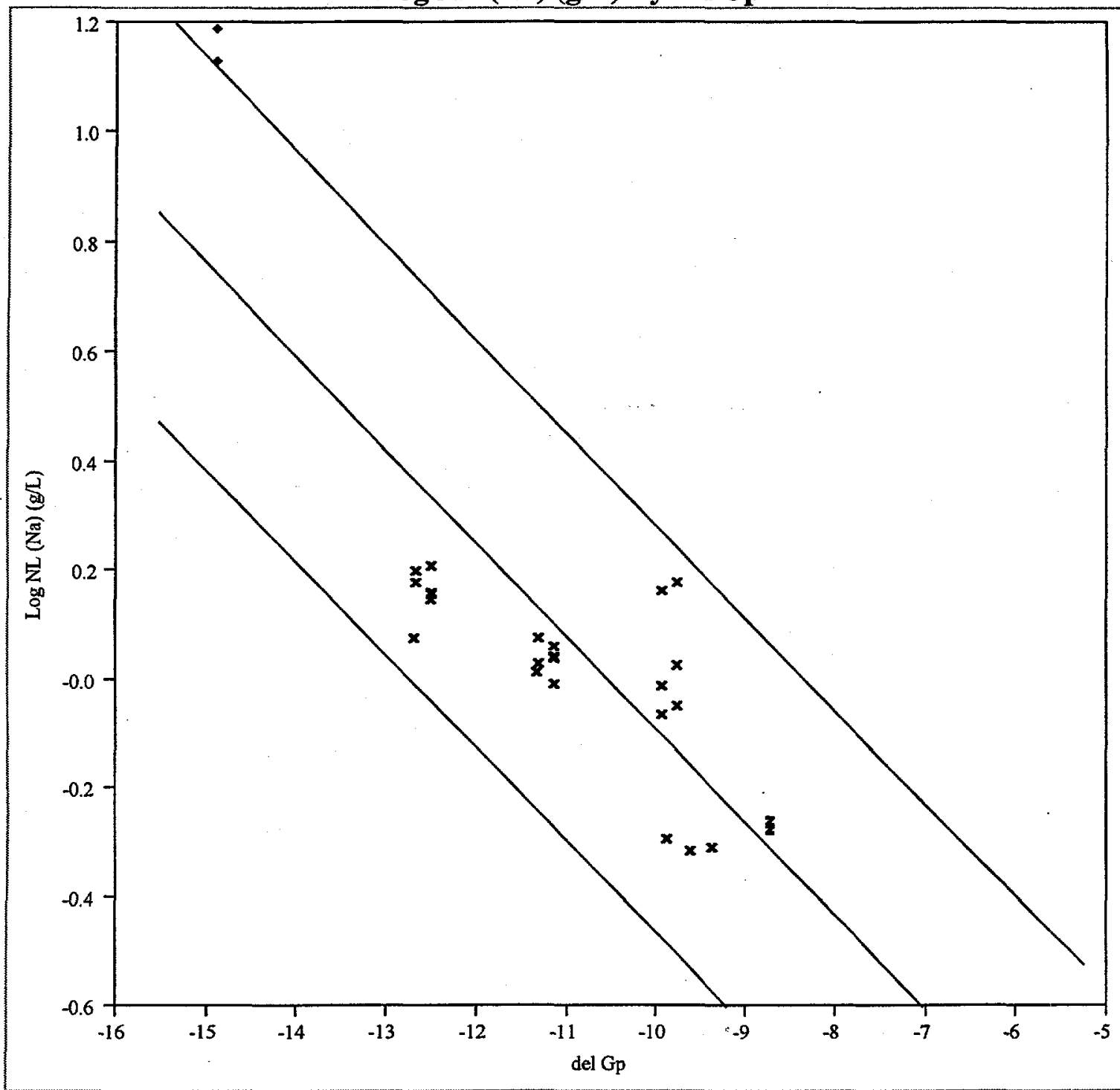

- Linear Fit

PCTs normalized and del $G_{p}$ determined from target compositions. 
Exhibit A.2: Durability Predictions Versus Measurements (continued)

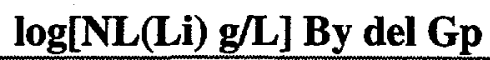

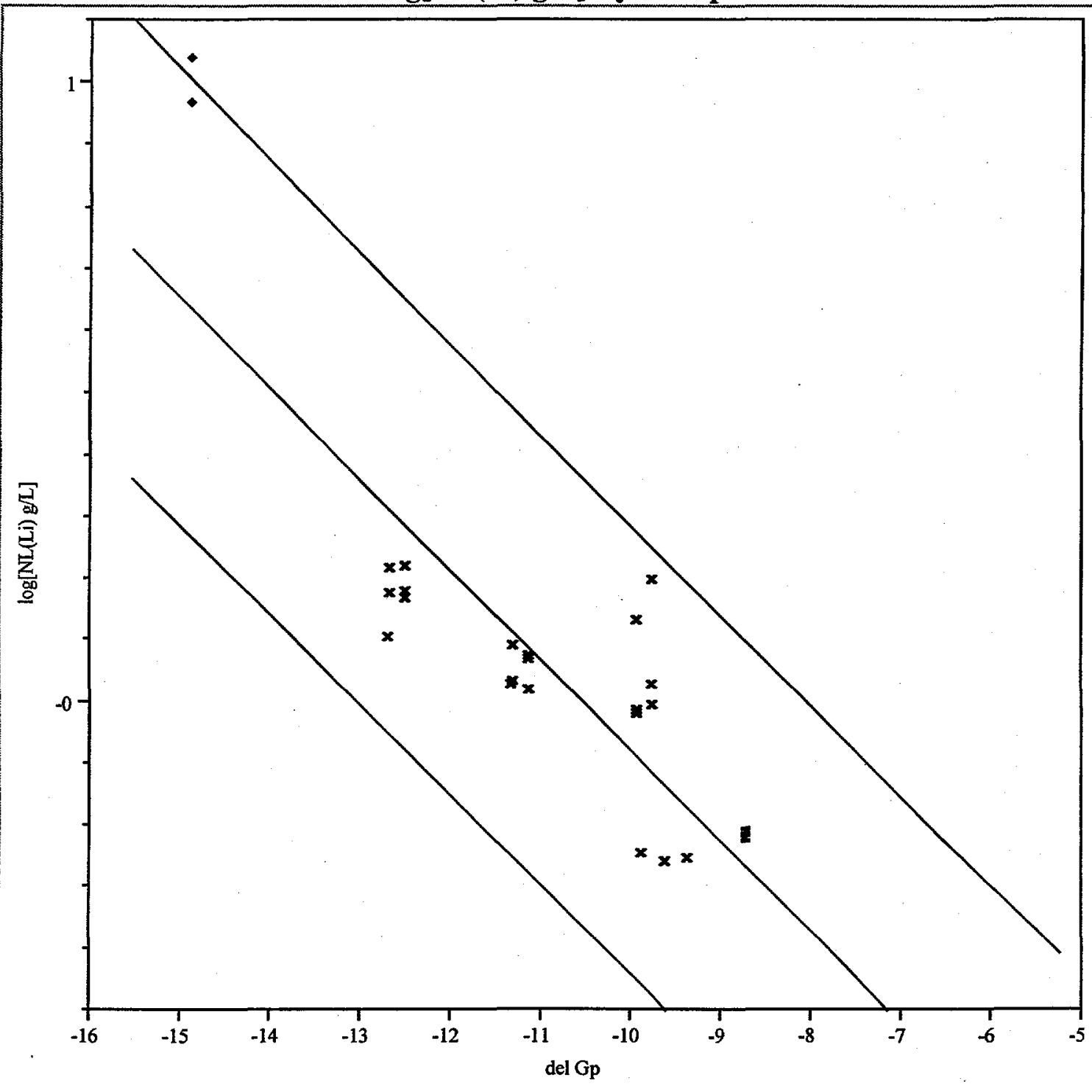

- Linear Fit

PCTs normalized and del $G_{p}$ determined from target compositions. 


\section{Distribution}

J. L. Barnes, 704-3N

N. E. Bibler, 773-A

D. F. Bickford, 773-43A

C. S. Boley, 703-H

K. G. Brown, 704-1T

J. T. Carter, 704-3N

J. J. Connelly, 773-41A

A. D. Cozzi, 77-43A

D. A. Crowley, 773-43A

R. E. Edwards, 704-25S

T. B. Edwards, 773-42A

H. H. Elder, 704-S

S. D. Fink, 773-A

J. R. Harbour, 773-43A

E. W. Holtzscheiter, 773-A

R. A. Jacobs, 704-3N

C. M. Jantzen, 773-A

R. T. Jones, 704-3N

W. D. Kerley, 704-S

D. P. Lambert, 704-1T

L. F. Landon, 704-1T

T. J. Lex, 703-H

S. L. Marra, 704-25S

D. B. Moore-Shedrow, 773-A

J. P. Morin, 703-H

J. E. Occhipinti, 704-27S

J.F. Ortaldo, 704-S

L. M. Papouchado, 773-A

D. K. Peeler, 773-43A

S. F. Piccolo, 704-3N

J. A. Pike, 704-3N

K. J. Rueter, 704-3N

P. L. Rutland, $704-196 \mathrm{~N}$

R. F. Schumacher, 773-43A

M. E. Smith, 773-43A

T. K. Snyder, 704-1T

P. C. Suggs, $704-196 \mathrm{~N}$

W. L. Tamosaitis, 773-A

R. C. Tuckfield, 773-43A

D. D. Walker, 773-A

W. R. Wilmarth, 773-42A

R. J. Workman, 773-A

TIM (4 copies), 703-43A 